\title{
Maximization of Nutrient Use Efficiency and Crop Production Through Fertigation
} Technologies: An overview

\author{
${ }^{1}$ Abou Seeda M.A., A. Khater ${ }^{1}$, S.A. Hammad ${ }^{3}$, E.A.A. Abou El-Nour ${ }^{2}$ and A.A. Yassen ${ }^{1}$ \\ ${ }^{1}$ Plant Nutrition Dept., National Research Centre, 33 El Buhouth St., 12622 Dokki, Giza, Egypt. \\ ${ }^{2}$ Fertilization Tech. Dept., National Research Centre, 33 El Buhouth St., 12622 Dokki, Giza, Egypt. \\ ${ }^{3}$ Soil and Water Dept., Agric. Mansoura University, Egypt.
}

Received: 30 May 2020/Accepted 10 August 2020 / Publication date: 15 August 2020

\begin{abstract}
The importance of fertigation in increasing productivity with efficient and reduced consumption of water and nutrients with practically, no pollution is emphasized. In modern farming systems, fertigation is widely practiced as a cost effective and convenient method for applying soluble fertilizers to crops. Along with efficiency and adequacy, uniformity is an important fertigation performance evaluation criterion. Fertigation uniformity is defined here as a composite parameter consisting of irrigation and fertilizer application uniformity indicators. The use of fertigation, coupled with micro-irrigation, has continued to increase since it was first introduced in horticultural cropping systems. This combination provides a technical solution whereby nutrients and water can be supplied to the crop with high precision in terms of time and space, allowing high nutrient use efficiency. However, the correct estimation of crop nutrient and water needs is fundamental to obtaining precise plant nutrition and high nutrient use efficiency in fertigated cropping systems. Increasing food demand and decreasing water resources have composed a kind of pressure to find new technologies for efficient use of water and fertilizers in agriculture. Such technology can be able to save irrigation water from $30 \%$ up to $50 \%$, as compared with surface irrigation, furthermore increasing crop yields and crop quality. Highest benefits of drip irrigation, some soil data such as, infiltration rate, soil texture and soil structure, crop characteristics and water resources properties, water quality, surface as will as well water, must be considered in system design, management and operation. Fertigation is an agricultural technique and application together with water and fertilizer to soil and/or plants, stimulates yield and fertilizer use efficiency as well; therefore, and under this technique leaching of nutrients is completely prevented. In order to utilize fertigation successfully, the four main factors must be considered: (a) the consumption rate of water and nutrients throughout the growth season that result in optimal yields, (b) response in uptake of different crops to nutrient concentration in the soil, (c) monitoring for total soil water potential, nutrients concentration in soil and percentage of elements in plants as a function of time, (d) root mass and distribution due to irrigation regimes as well as soil types.
\end{abstract}

Keywords: Fertigation technique, drip irrigation, water use efficiency, watershed, management development

\section{Introduction}

The most important components that responsible for the development of stable societies and civilizations are Fertile and productive soils from ancient days. Soil fertility refers to the capacity of a soil to supply the essential nutrients to the plants the primary producers in correct quantity, at correct time in balanced proportion according to the crop requirement (Singh and Singh, 2015). World's population continues to grow rapidly, but the productive cropped land area is decreasing very rapidly due to industrialization and urbanization (Oliver and Gregory, 2015). The need to supply enough food for a growing world population stimulated interest to increase input efficiency utilizing varieties with high yield potential along with improved water and fertilizer use efficiency. This has practical significance in terms of increasing scarcity for water on one hand since the demand for water is increasing at an alarming rate, while on the other hand; precision farming was initiated to improve the fertilizer use efficiency using newly available technologies by different rates and combinations as needed for the crop. Precision farming and protected cultivation plays a major role in increasing the productivity from the decreasing cropped area with high water and fertilizer use efficiency utilizing

Corresponding Author: Abou Seeda M.A., Plant Nutrition Dept., National Research Centre, 33 El Buhouth St., 12622 Dokki, Giza, Egypt. E-mail: mabouseeda@gmail.com 
latest technologies. The importance of these aspects have been reviewed by many workers (Keller and Bliesner, 1990; Mondal and Tewari, 2007). Fertilization and irrigation are two of the most important factors in crop production, as they strongly affect the yield and quality of cultivated crops (Goldberg, et al., 1976; Bar-Yosef 1999). The total area cultivated by micro-irrigation worldwide increased from 1.1 million ha in (1986), Reinders (2007) to roughly 11.1 million in 2015 ICID (2016). This astonishing growth in the use of micro-irrigation is mainly due to (i) its high irrigation efficiency (up to $95 \%$ of applied water Howell, (2011), which partially contributes to solving the water shortage problems associated with both poor quality and low quantity in some cultivated areas and (ii) the progressive development of irrigation technologies that have substantially reduced the cost of equipment for microirrigation systems. Horticultural crops are generally high-value, so irrigation is fundamental for obtaining high yield and quality for open-field-vegetable crops, and it is required for protected vegetable crops (Pardossi, and Incrocci, 2011).

Fertigation is the agronomic operation in which fertilizer is dissolved in the irrigation water and delivered to the root zone by the irrigation system (Hagin, and Lowengart, 1995). This combination provides the technical capacity for precise mineral nutrition, both spatially and temporally. The first scientific application of fertigation was in 1958 in the USA Bryan, and Thomas, (1958) using sprinklers while the combination with drip irrigation was first applied in Israel on tomato crops (Sagiv and Kafkafi, 1976). Fertigation generally allows for a significant increase of nutrient use efficiency in terms of plant nutrient recovery, with much higher results (up to 90\%) than in other fertilizer application systems (4045\%) (Agostini et al., 2010; Solaimalai et al., 2005). The main advantages of fertigation are the increased flexibility to split the fertilizer dose according to the uptake rate of the crop, an improved distribution of fertilizer in the root zone, and the possibility of maintaining a low (but constant) nutrient level in the soil solution. Therefore, the use of fertigation has been found to reduce the run-off of mobile nutrients such as $\mathrm{N}$ by up to $70 \%$ compared with conventional fertilizer applications (Solaimalai et al., 2005). Micro-irrigation systems enable higher water use efficiency only if combined with precise irrigation scheduling Photo (1).
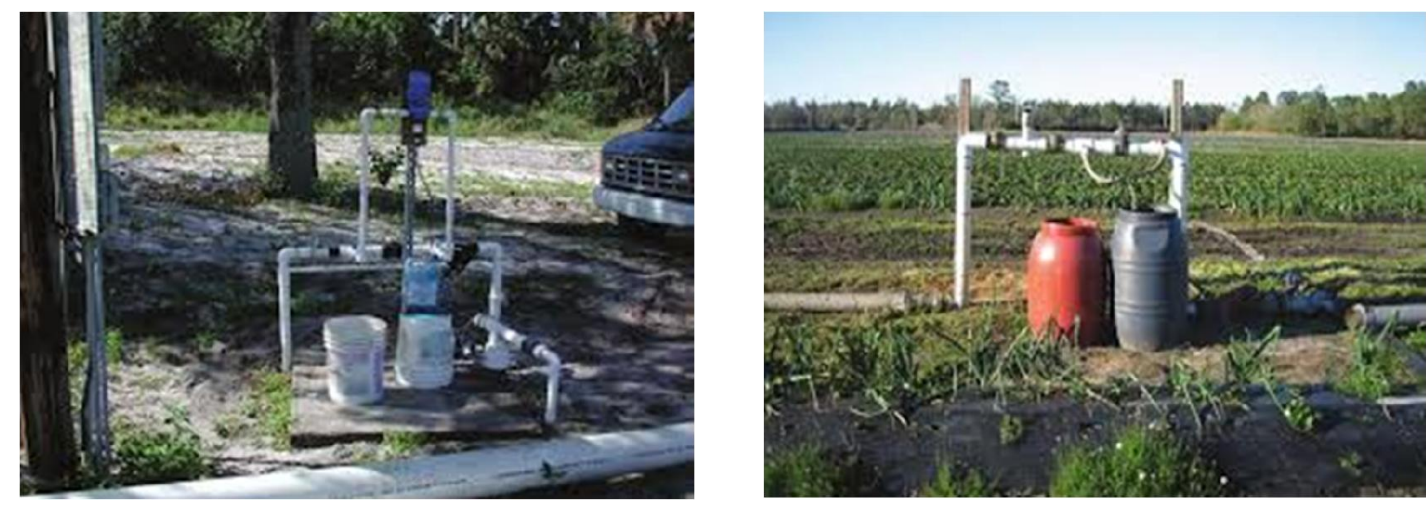

Photo 1: Illustrates (A) back-flow prevention made of two ball valves and a vacuum breaker are placed upstream of the Venturi injector, (B) Injection made possible. After Simonne et al., (2017).

Simonne et al. (2017), reported that Drip irrigation is an irrigation method that allows precisely controlled application of water and fertilizer by allowing water to drip slowly near the plant roots through a network of valves, pipes, tubing, and emitters.

In many areas of the world, the adoption of drip irrigation without precise irrigation management has not increased the water use efficiency of vegetable crops, and run-off of nutrients (mainly N) from the

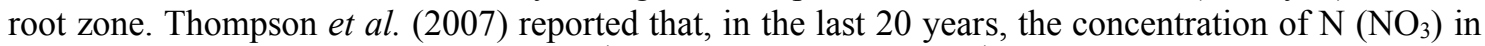
the aquifers increased from a few $\mathrm{mg} \mathrm{L}^{-1}$ to more than $100 \mathrm{mg} \mathrm{L}^{-1}$. Similar results were observed in central California (Harter, and Lund, 2012). However, in the present review, irrigation scheduling is not analyzed in detail, as other reviews on this topic are reported in this special issue Alvino, and Marino (2017), George, (2017). Mark et al. (2015) reported that riparian seepage zones in headwater agricultural watersheds represent important sources of nitrate-nitrogen $\left(\mathrm{NO}_{3}-\mathrm{N}\right)$ to surface waters, often connecting $\mathrm{N}$-rich groundwater systems to streams. In this study, we examined how $\mathrm{NO}_{3}-\mathrm{N}$ 
concentrations in seep and stream water were affected by $\mathrm{NO}_{3}-\mathrm{N}$ processing along seep surface flow paths and by upslope applications of $\mathrm{N}$ from fertilizers and manures.

The research was conducted in two headwater agricultural watersheds, FD36 (40 ha) and RS (45 ha), which are fed, in part, by a shallow fractured aquifer system possessing high (3-16 mg L $\left.{ }^{-1}\right) \mathrm{NO}_{3}-$ $\mathrm{N}$ concentrations. Data from in-seep monitoring showed that $\mathrm{NO}_{3}-\mathrm{N}$ concentrations generally decreased down seep (top to bottom); indicating that most seeps retained or removed a fraction of delivered $\mathrm{NO}_{3}-\mathrm{N}$ (16\% in FD36 and 1\% in RS). Annual mean N applications in upslope fields (as determined by yearly farmer surveys) were highly correlated with seep $\mathrm{NO}_{3}-\mathrm{N}$ concentrations in both watersheds (slope: $0.06 ; R 2=0.79 ; p<0.001$ ). Strong positive relationships also existed between seep and stream $\mathrm{NO}_{3}-\mathrm{N}$ concentrations in FD36 (slope: $1.01 ; R 2=0.79 ; p<0.001$ ) and in RS (slope: 0.64 ; $R 2=0.80 ; p<0.001$ ), further indicating that $\mathrm{N}$ applications control $\mathrm{NO}_{3}-\mathrm{N}$ concentrations at the watershed scale. Our findings clearly point to $\mathrm{NO}_{3}-\mathrm{N}$ leaching from upslope agricultural fields as the primary driver of $\mathrm{NO}_{3}-\mathrm{N}$ losses from seeps to streams in these watersheds and therefore suggest that appropriate management strategies (cover crops, limiting fall/winter nutrient applications, decision support tools) be targeted in these zones.

Fertigation is the agronomic operation in which fertilizer is dissolved in the irrigation water and delivered to the root zone.

\section{Fertigation as a technology tools}

Water is essential to grow crops, to provide food and to decrease drought risks. Irrigated agriculture globally uses more than 70\% of water (Khokhar, 2017; Anonymous, 2019a). Use of surface irrigation methods in the world, especially in developing countries, is still preponderant. The conventional irrigation methods use water excessively; it is mainly dependent on the nature of these methods and farmers' conditions. In arid and semiarid conditions, increasing agricultural production is mainly dependent on irrigation, surface irrigation use much more water as compared to the pressurized irrigation systems such as sprinkler and drip irrigation. Increasing food demand and decreasing water resources have composed a kind of pressure to find new technologies for efficient use of water and fertilizer for agriculture. In addition, protection of soil and water resources and environmental sustainability are other crucial factors to be considered. Thus, efficient and less water and fertilizer use is significantly important in terms of environmental protection (Hagin et al., 2003). A considerable amount of water is lost as leakage and/or evaporation during storage and transport to the fields where the crops are grown in irrigated agriculture. The runoff is also an important loss considering surface irrigation (Wallace, 2000). Thus, the most important issue on use of water resources such as microirrigation is to minimize the amount of water used in irrigated agriculture through increasing, water use efficiency and to shift to a more sustainable use of water in agriculture, improvement in water use efficiency is required (Barua et al., 2018). Such target can reached through, using water efficient irrigation systems, appropriating irrigation scheduling, managing of watershed development, growing drought tolerant crops, dry farming, rotational grazing, use of mulch and compost, cover crops, conservation tillage, and organic agriculture. One of the most important ways is to shift to the pressurized irrigation systems such as drip and sprinkler irrigation. The plant root zone receives water directly into the root zone by means of these systems. However, reducing the evaporation that happens with sprinkler irrigation systems is another important issue.

Therefore, the adoption of drip irrigation, low-pressure sprinkler systems, and other water saving technologies and practices, has been becoming more widespread (Üzen, Çetın and Karaer, 2013; OECD, 2010). Researches have shown that drip irrigation can gradually save water use by about $30 \%$ to $70 \%$, increasing crop yields production by about $20 \%$ to $90 \%$, depending on, climatic condition as well as soil and crop characteristics, and farmers practices for designed, installed operated (Postel et al., 2001; Çetın and Bilgel, 2002) Fig.(1). 


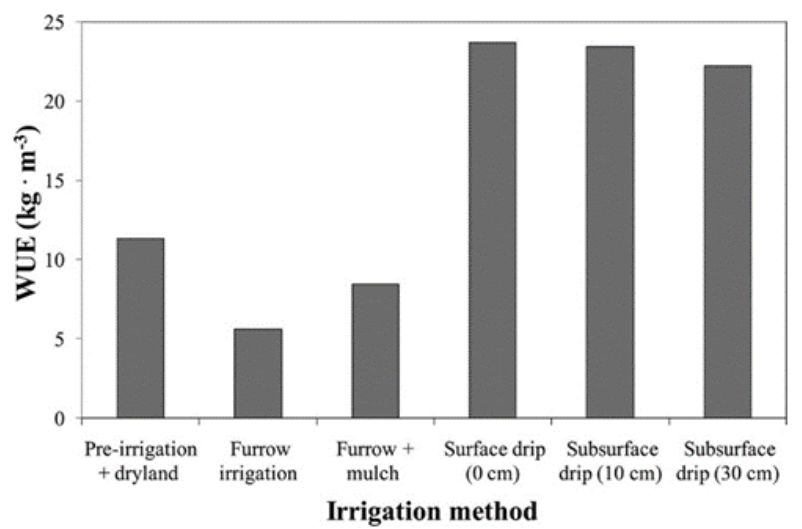

Fig. 1: Water use efficiency of 'Caravelle' cantaloupe as affected by the irrigation method (mean values of 4 years). Irrigation efficiencies of three irrigation systems (furrow, sprinkler, and drip irrigation) were compared (After Leskovar et al., 2001)

Stefania De Pascale et al. (2011) reported that drip irrigation is very common in greenhouse horticulture. Higher yields, improved WUE, and higher produce quality have been reported for drip irrigation systems as compared with other irrigation methods for different vegetable crops, including potato Unlu et al., 2006), cucumber (Yuan et al., 2006), bell pepper (Sezen et al., 2006), okra (Tiwari et al., 1998), cabbage Tiwari et al., 2003), eggplant Aujla et al., 2006), and watermelon (Srinivas et al., 1989). Some advantages of drip irrigation include improved water and nutrient management, improved saline water management, potential for improved yields and crop quality, and greater control of applied water resulting in less water and nutrient loss through deep percolation Photo (2).
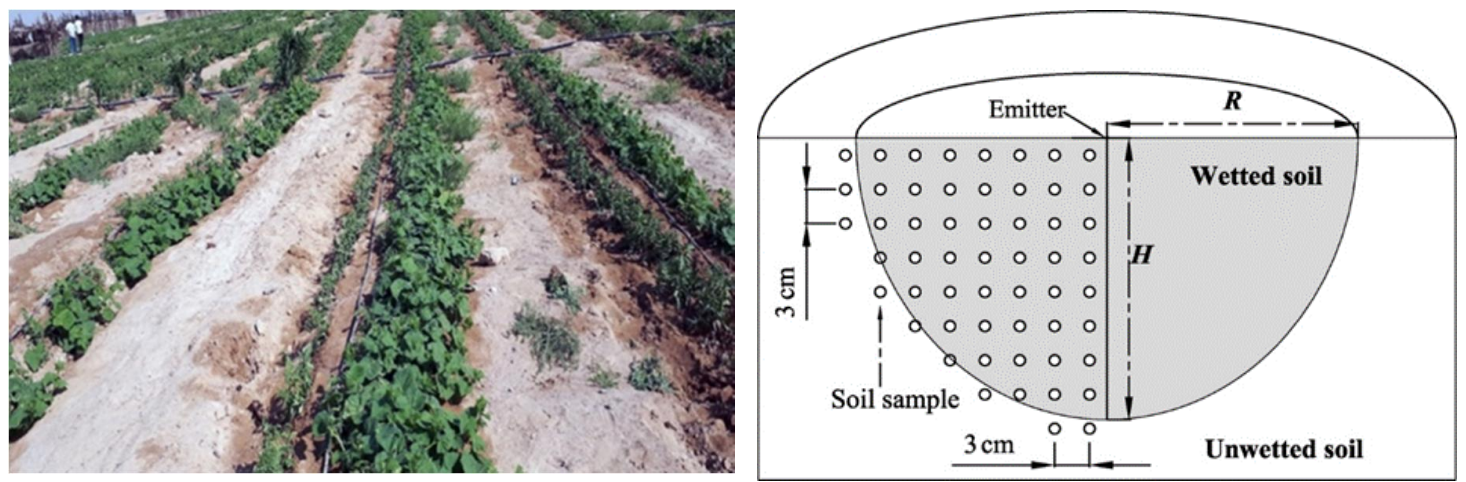

Photo 2: Illustrates drip irrigation improved saline water management, and nutrient management, improved

Use of subsurface drip irrigation has progressed from being a novelty used only in experimental fields to an accepted method of irrigation for both tree and vegetable crops (Lamm and Camp, 2007). Subsurface drip irrigation on lettuce (Thompson and Doerge, 1995), Thompson et al. (2007) tomato, sweet corn (Z. mays), and cantaloupe (Ayars et al., 1999) has significantly increased yield and WUE in all these crops. Subsurface drip irrigation may increase WUE in semiarid environment under saline conditions by increasing yield (Ayars et al., 1999). However, the choice of the proper irrigation technology is highly site-specific, reflecting regional (field characteristics and climate), technical (water supply and crop characteristics), and market (crop prices, energy cost, labor supply) factors (Lamm and Camp, 2007). Subsurface drip irrigation can potentially provide a more stable soil water and nutrient environment for optimal crop growth, and be effective for salinity management, soil water redistribution, and application of agrochemicals (Lamm and Camp, 2007). Farmers producing highvalue crops in arid and semiarid regions have a greater likelihood of benefiting from adopting drip irrigation and subsurface drip irrigation than farmers producing low-value crops in humid and sub 
humid climates (Wichelns, 2007). Alternate furrow irrigation is another technique that appears promising (Kang et al., 2000).

The resulting efficiency, of course, depends on climatic, soil and crop characteristics and farmer practices. Thus, water saving ratio can vary depending on these conditions. The advantages of drip irrigation could be specified as water saving (30-50\%), higher crop yield, maximum utilization of available water, no water being available for weeds, high efficiency in the use of fertilizers, less weed growth, lower labour, no soil erosion, possible sophisticated automatic control, no runoff, no leaching of fertilizers into ground water, and less evaporation losses compared to surface irrigation Photo (3) However, drip irrigation has some limitations such as clogging, salinity hazards at the top of soil profile for arid and semi-arid regions, higher investment costs compared to surface irrigation, higher skills and experiences required for its design, install, operation and management.
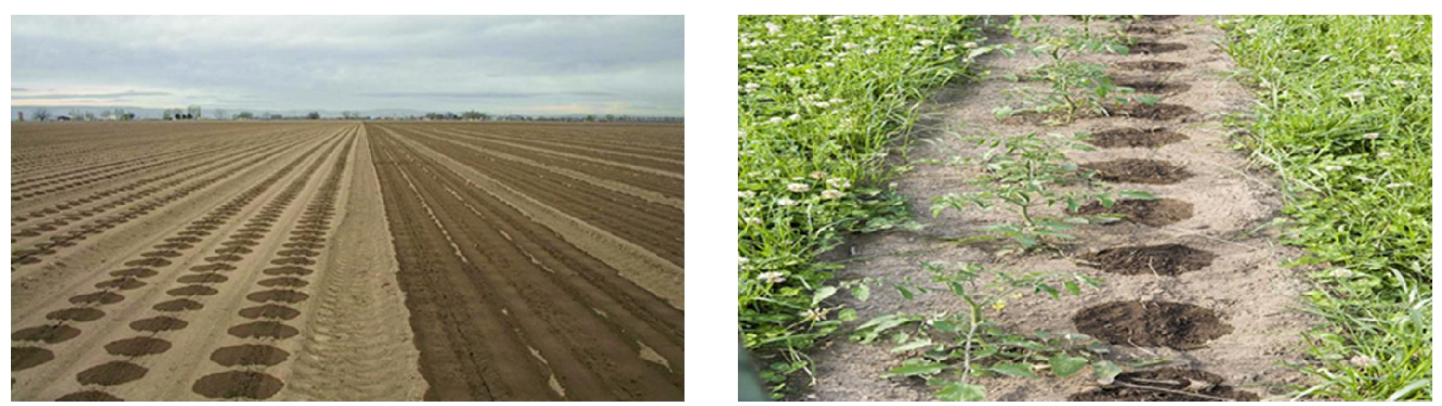

Photo 3: Represents the differences between drip and furrow, watering through emitters reduce weed growth and reduces labor costs. However, furrow or flood irrigation provides water to the entire field, leading to 10 to 14 times more weed more labor to remove weeds

In order to get the highest benefits using drip irrigation, some soil data should be involved such as soil properties, crop characteristics and water resources properties must be considered for drip system design, management and operation. Among others, the lateral design, dripper discharge, dripper space and requirement of energy are the most important components of drip irrigation system design. The main problems in the use of drip irrigation systems are physical (sand and suspended solids) biological (bacteria, fungi and algae, slime) and chemical causes (mineral precipitation, lime content of water) of emitter clogging. The common elements are calcium, magnesium, iron and manganese that may clog drip emitters by precipitation and sedimentation. The most important irrigation water parameters in use of drip irrigation systems are content of suspended solids, dissolved solids, iron, manganese and bacteria (total plant count $/ \mathrm{ml}$ ), $\mathrm{pH}$, hardness (as $\mathrm{CaCO}_{3}$ ). Use of fertilizers together with irrigation Photo (4).
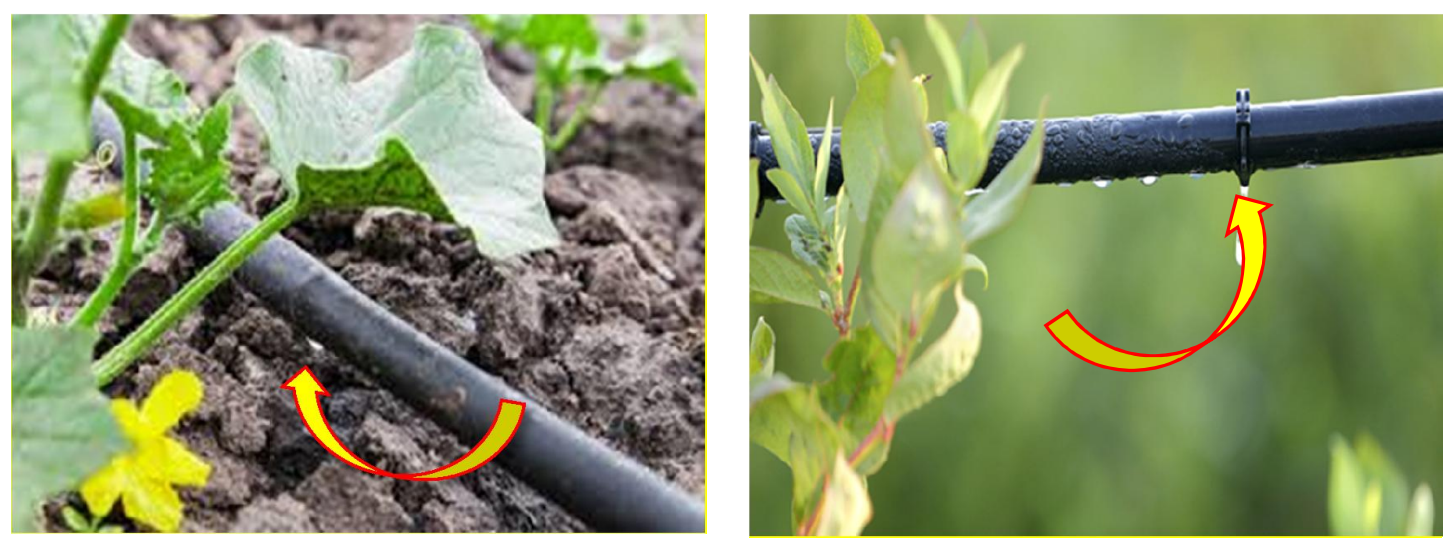

Photo 4: Drip irrigation systems provide a favorable environment for bacteria, fungi and algae that can cause slime accumulation. Bacterial slime can be a direct cause for clogging of drippers, but it can also induce mineral particles to stick together and form aggregates large enough to clog the emitter openings. This phenomenon is specifically significant when manganese, sulfide and iron are present in the water. 
Drip irrigation enable higher efficiency of water and fertilizer use, considering the conventional fertilizing, this technique has many advantages and is a kind of modern technology. Thus, the combination between irrigation and fertilization has been widely used for the cultivation of crops and fruit production (Yan, Dai and Jia, 2018). Soluble fertilizers added at any concentrations to crops can be applied through irrigation systems, which created wetted area of soil (Chartzoulakis and Bertaki, 2015). Fertigation can be practiced for any irrigation system, however, fertilizers added by casting surface irrigation and open canals might be inappropriate for nutrient distribution in the field area. Fertigation can be applied as an integral part of plant nutrient management and specifically under micro irrigation; which providing a concentrated and space-limited root system within the wetted soil volume. On the other hand, soluble $\mathrm{N}$ fertilizers such as urea, ammonium sulphate, ammonium nitrate, and liquid urea are easily injected and applied through drip and micro sprinkler systems and are commonly used for fertigation in vine and tree fruit crops (Schwankl, et al., 1998; Bar-Yosef, 1999; Kafkafi and Tarchitsky, 2011).

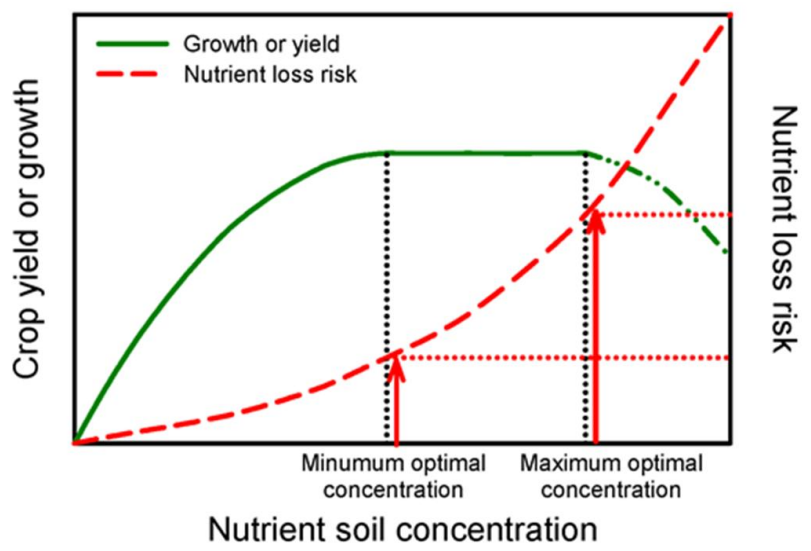

Fig. 2: The relationship between crop growth (or yield) and nutrient soil concentration in the root zone. After Incrocci et al. (2017)

Incrocci et al. (2017) reported that, main goal in efficient fertigation management is to satisfy both the crop needs and to minimize nutrient losses. To attain this goal, it is necessary to accurately estimate three main variables: (A) crop nutrient requirement; (B) soil nutrient availability; and (C) nutrient delivery to match crop development. Fertigation prevents losses of nitrogen because there is no leaching, and directly supplied to root zone particularly in available forms, consequently, controlled and application cost decreased, (Chartzoulakis and Bertaki, 2015).

\section{Nutrients applied by fertigation}

Water-soluble fertilizers can be applied through Fertigation, except phosphorous and microelements which is not advised in practice, as their precipitation can easily gradually occur at higher than 7.0, resulting in clogging of the irrigation system Bar-Yosef, (1999). Nitrogen can be applied in different chemical forms, nitrate (potassium nitrate, calcium nitrate, and magnesium nitrate salts), ammonium (ammonium nitrate, ammonium sulphate), in the most common and urea fertilizers. Nitrate is an anion not retained by the soil, resulting in the most mobile nutrient beyond the crop root zone. Several researchers reported that $\mathrm{NO}^{-3}$ moves and leached away throughout soil profile. Nitrate tends to accumulate at the periphery of the wetted soil under intensive water irrigation, nitrate is transported to the deeper soil profile, away from root zone (Bar-Yosef, 1999; Solaimalai et al., 2005; Hanson et al., 2006). Ammonium is not very mobile fraction, retained by soil components, and does moves less than 10-15 cm from the emitter Li et al. (2004), however urea is highly solubilized fraction and is not adsorbed by soil colloids (Solaimalai et al. 2005). Distribution and movement of urea fertilizers in the root zone gradually depends on time of irrigation and soil properties. Haynes, (1990) reported that, there is a similarity of urea and nitrates transported in the root zone particularly in sandy soil, through Fertigation Both were more evenly distributed vertically and laterally in the soil profile up to $15 \mathrm{~cm}$ from the emitter Fig. $(3 \& 4)$ 


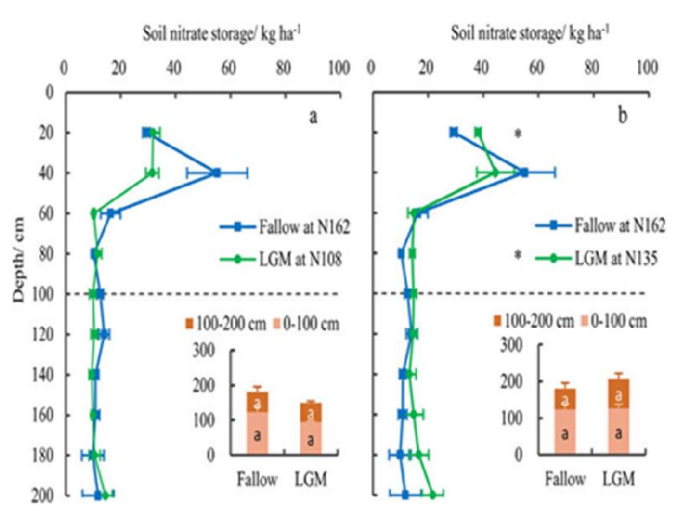

Fig. 3: Represents residual nitrate storage distribution in the soil profile for the fallow treatment with $162 \mathrm{~kg}$ ha -1 and the average of 3 LGMs with $108 \mathrm{~kg}$ ha -1 (a) and $135 \mathrm{~kg}$ ha -1 (b) of synthetic $\mathrm{N}$ after wheat harvest; after Yan et al. (2018).
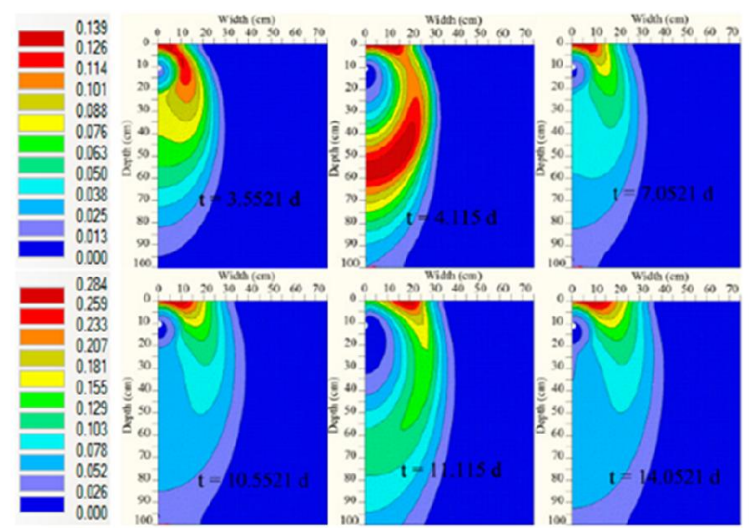

(c)

Fig. 4: Spatial distributions of (a) urea (b) ammonium (c) nitrate $\left(\mathrm{mg} \mathrm{cm}^{-3}\right)$ for fertigation (A) for various days at the time of urea application for the sandy loam soil with $1 \mathrm{~L} \mathrm{~h}^{-1}$ emitter discharge (Mohamed et al. 2019)

Jiusheng and Yuchun (2010) reported that drip line depth and layered-textural soil greatly affected water and nitrate distribution. Wetted depth increased with drip line depth and initial soil water content for both uniform and layered soils. The distribution pattern of water in the layered soils was controlled by the layering sequence and the drip line position relative to the interface between two soil layers. Water accumulation occurred in the fine textural layer of soil for the layered soils. For the sandy loam soil (SL), positioning the drip line below the interface led to much water $(89 \%)$ moving to the sub layer of loam soil than positioning the drip line above the interface (73\%). For the loam-sandy-loam soil (LSL), positioning the drip line in the top layer of loam soil resulted in $77 \%$ of water applied distributed in the top layer, while positioning the drip line in the bottom layer of loam soil resulted in $93 \%$ of water applied distributed in the bottom layer. Measurements of nitrate distribution showed that nitrate concentration in the proximity of the drip line and of the water accumulation zone approximated the input concentration while nitrate accumulated at the boundary of the wetted volume for both uniform and layered soils tested. The results from this study suggest that the drip line depth should be carefully selected in the design of subsurface drip irrigation systems for layered soils to obtain a target distribution of water and nitrate. Nitrification of Ammonium and urea can contribute to $\mathrm{NO}^{-3}$ distribution and acidification in the root zone.

Phosphorus is present in the soil solution in anionic forms, general, it tends to accumulate within a few centimeters around the emitters. Phosphate salts in fertigated systems have been previously limited Bar-Yosef, (1999), Hanson et al. (2006). Currently, phosphoric acid or urea-phosphate are commonly applied, for prevention clogging due to the precipitation of $\mathrm{Ca}$ and $\mathrm{Mg}$ as well as better distribution of phosphorous in the soil Fig.(4) 
Potassium, like $\mathrm{NH}^{+4}$, is a nutrient subject to CEC retention, and it moves slowly in the root zone, in some cases, Potassium can move beside the waterfront, with a better distribution along the wet root zone. Under such conditions, K run-off can occur Bar-Yosef, (1999), Hanson et al. (2006).

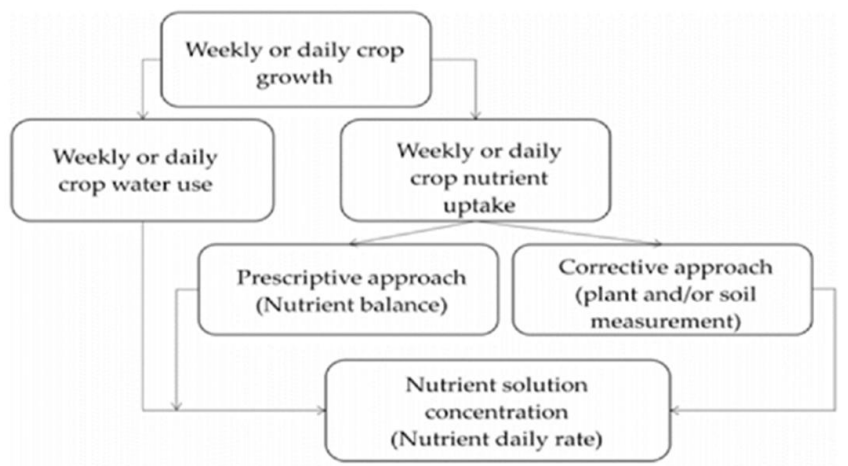

Fig. 5: Conceptual framework for the calculation of the fertilizer supply rate in fertigated crops, following different theoretical approaches.

Thompson et al. (2007), stated that many new technologies have been developed and validated for precise nutrient and irrigation management; not sufficiently exploited by growers. In practice, nutrient management as well as water supply particularly in cropping systems are based on growers' experiences, which is mainly stable in fertilization plans. There are two main approaches can be used for efficient fertigation management Fig (5). Firstly, doses of the fertilizer used can estimated before cultivation, taking into account all variables that may change the concentration of nutrients in the root zone and data collected on the cultivation system, which used to draw in advance a "prescriptive" fertilization plan (Giller et al., 2004). Through the approach, desired nutrient concentration can be calculated as the ratio between the amount of nutrient and water taken up by the crop in the same period. Secondly, fertigation management is accomplished through a "corrective" approach: a nutrient solution is applied to the crop and its nutrient composition is periodically adjusted because of plant and/or soil measurements, in order to avoid nutrient excesses or deficiencies (Giller et al., 2004). Both approaches can be integrated for the same crop: the prescriptive fertilizer dose is then calculated before planting, and afterwards the fertilizer supply rate is fine-tuned according to the seasonal variations of crop nutritional status, detected by soil and/or plant measurements.

The application of microelements through fertigation water requires using chelated forms such as EDTA and EDDHA to avoid precipitation (Solaimalai et al., 2005). The observed nutrient distribution in fertigation is mainly due to the specific characteristics of the single ions, and soil hydraulic and chemical properties Abalos et al. 2014, other factors, can decreasing or increasing the mobility of ion in the soil also depend on fertigation and irrigation frequency. Shedeed et al. (2009), Farneselli et al. (2015), they stated that frequent supplies of low amounts of nutrients with irrigation water gradually increased the availability of N, P and K particularly in root zone. Furthermore, increasing the quantity and quality of the tomatoes. Badr and El-Yazied (2007) examined the influence of different fertigation frequencies, (from one to 14 days) on tomatoes with two different amounts of $\mathrm{N}$ (200 and $300 \mathrm{~kg} \mathrm{~N}$ ha-1). Mohamed et al. (2019), described the effect of changing emitter discharge and the application of three fertigation strategies on urea transport, transformation and leached nitrate below the root zone of onion under drip irrigation in sandy loam, loamy, and silty loam soils. Three fertigation strategies were considered as the following; strategy $(\boldsymbol{A})$ with one-hour duration starts after the beginning of the irrigation cycle by 15 minutes, strategy $(\boldsymbol{B})$ with one-hour duration ends 15 minutes before the end of the irrigation cycle and strategy $(\boldsymbol{C})$ of one-hour duration in the middle of the irrigation cycle. Simulations were conducted for 35 days, with a mid-growth stage of the green onion, Smith (1999) while the efficiency of the drip system was $80 \%$. The HYDRUS $2 / \mathrm{D}$ model included the processes of hydrolysis, nitrification, mineralization, and ammonium adsorption. Emitter discharge rates were significant affect the soil water distribution as well as plant uptake in sandy loam however, no significant affect in loam and silt loam soils. Silty loam soil showed a smaller numbers of emitters and larger spacing among them are recommended in the design of irrigation system for shallow-rooted 
crops. They also stated that, increasing of emitter discharge, nutrient added tends to move downwards particularly in coarse-textured soil Fig. (6).
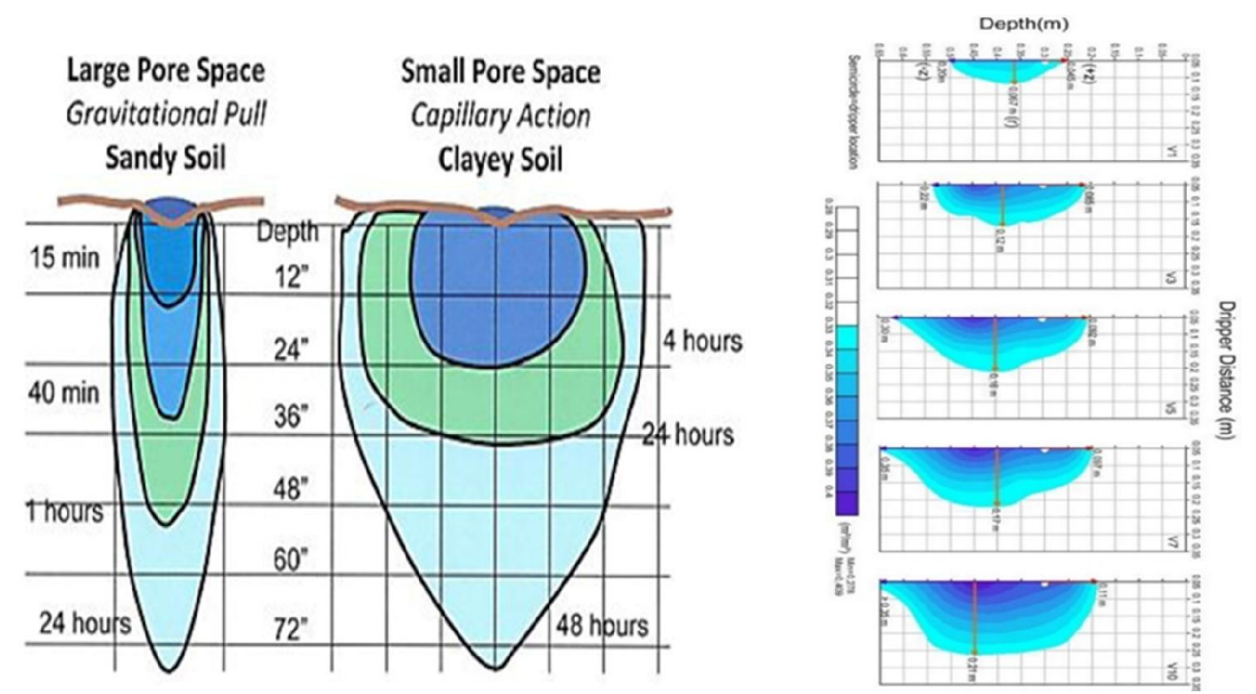

Fig. 6: Illustrated comparative movement of water in sandy and clayey soils. In sandy soils, water readily moves downward due to the gravitational pull. In clay soils, water slowly moves in all direction by capillary action. After Marcel et al. (2015)

For fine-textured loam and silt loam soil, nutrient moved outwards (laterally) the soil domain. The application of urea fertigation strategy $(A)$ increased nitrate concentration near the drip line and the plant uptake as well. There is no accumulation of urea among the three fertigation strategies for the three examined soil types. During the time, being urea concentrations gradually decreased due to hydrolysis and associated nitrification to ammonium, and gradually diminished particularly around the emitter near the edge of the wetting zone. Application of urea at the middle of irrigation gives the highest nitrate concentrations, which can be leached down the root zone, and be avoided. Fertigation at the beginning of irrigation is the best for the high nutrient plant uptake particularly for sandy loam and loam soil while, for silty loam soil, the fertigation at the end of irrigation event is recommended. Therefore, physical properties of the investigated soil play an important role for time of Fertigation event.

The total crop $\mathrm{N}$ uptake was considerably higher in the treatment with more frequent applications. Jiusheng and Yuchun (2010), concluded that frequently doses of $\mathrm{N}$ in small every day can reduce the variation in nutrient concentration in the root zone and possible related salinity stress; increasing nutrient availability for the crop; and reduces the risk of N leaching. Shedeed et al. (2009) stated that, daily $\mathrm{N}, \mathrm{P}$ and $\mathrm{K}$ added with irrigation water particularly in tomato gradually increased the availability of the nutrient added in the root zone, improving yield and quality of the crop furthermore reducing losses of both $\mathrm{N}$ and $\mathrm{K}$, particularly in sandy soils. Taking into account Fertigation regimes are not easy to manage and can increase losses of through evaporation particularly from wet soil surface.

\section{Most best management of fertigation}

In modern agriculture, accumulation of nitrates can reach toxic levels due to extensive use of nitrogen fertilizers, cultural methods, farming policies in multiple areas of the world, thereby increasing concerns about the availability of hygienic food supply and environmental hazards. Over the past few decades, global interest in achieving greater output through intensive fertilization has been a growing trend. The fertilizer based on urea or ammonium mainly yields ammonium, which is then transformed to nitrate through the oxidation process that is biologically mediated. Nitrate tends to accumulate differently in distinct crop plants and distinct components of agricultural commodities based on species, crop variety, genetic history, environmental circumstances, harvest phase, post-harvest storage conditions, agronomic variables, nature, and fertilizer application rate. 
Nitrate is the dominant form of $\mathrm{N}$ that is readily absorbed by most plants to assimilate and eventually transform into biomass production (Colla et al., 2011). However, in case of higher nitrate intake relative to its assimilation, it tends to accumulate in roots, tubers, bulb, stem, leaves, fruit, and seeds. Nitrate accumulates prominently in leafy vegetables and nonleguminous plants (Santamaria, 2006). Nitrate exposure to humans is primarily due to the consumption of raw vegetables, seeds, drinking subterranean water, and processed food (Rathod et al., 2016). However, although nitrate is not harmful to human life, its decrease to nitric oxide, nitrite, and $\mathrm{N}$-nitroso compounds mediated by oral bacteria and salivary enzymes may pose a related danger of bladder/gastric cancer and methemoglobinemia syndrome (Ahmed et al., 2017; Parks et al., (2008). Consumption of nitrite by fruits and vegetables is relatively small because it is extremely cytotoxic to plant cells and is continually kept to a minimum level (Riens and Heldt 1992). Nitrate accumulation in different plant crops and tissues relies on the scheme of agriculture, current environmental circumstances, species, genotype, plant range, pre-harvest variables, agronomic factors, harvest phase, and post-harvest factors (Andrews et al., 2013; Colonna et al., 2016). Post-harvest variables such as plant biomass storage setting may cause or impede endogenous nitrate reduction to nitrite. (Santamaria et al., 2001), reported that factors affecting crop plant nitrate accumulation are genetic background, environmental factors such as light circumstances and agronomic variables.

\section{Optimization of nitrate accumulation}

The availability of reducing nitrate in soil for plant uptake were used by different approaches, such as (i) Substitution nitrate-based fertilizer with ammonium Borgognone et al. (2013); (ii) adoption of nitrate-free liquid fertilizers Marsic and Osvald (2002); (c) Using of plant genotypes with low nitrate accumulation. (Burns et al. (2011); (iii) Possibility of nitrate starvation up to 5 days before harvest Borgognone et al. (2016); (iv) Replacing calcium nitrate $\boldsymbol{C a}$ (NO3) $)_{2}$ with calcium oxide (CaO) Borgognone et al. (2016); (v) Reducing nitrate through using light spectral fluxes particularly in crop manufacturing (Gaudreau et al., (1995). Anjana et al. (2007) stated that such research can clarifies multiple environmental, agronomic, and genetic factors to mitigate the accumulation of nitrate in multiple plant crops and tissues. Nitrates were absorbed through the plant roots which quickly transferred through xylem vessels via the transpiration stream. The absorption of nutrients from the root surface may be passive where a nutrient enters root with the absorbed water, e.g., nitrate entry into the root; whereas an active process requires another molecule or ion called the carrier (Epstein 1956) Fig. (7).
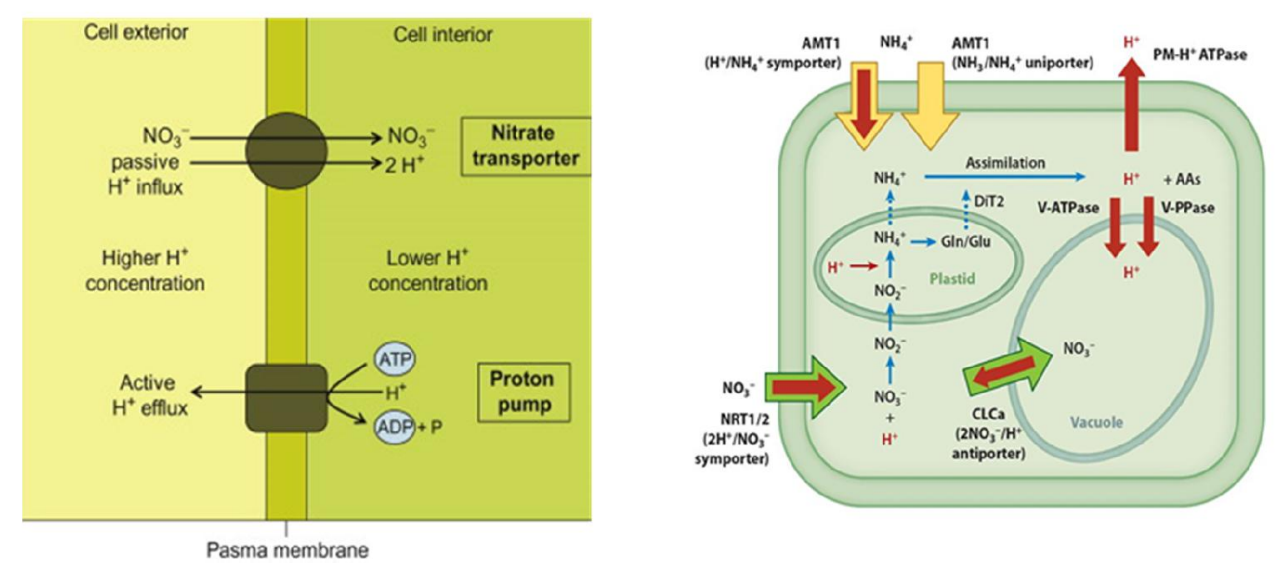

Fig. 7: Illustrates passive and active absorption of nitrates

Plant tissues with big laminae tend to accumulate more nitrate than plant tissue with compact laminae such as stem, petiole, fruit, and hypogeal storage bodies (Chen et al., 2004).

Santamaria et al. (1999) reported that Nitrate content in plant tissues occurs in the following order: petiole $>$ leaf $>$ stem $>$ root $>$ inflorescence $>$ tuber $>$ fruit $>$ seeds. Nitrate accumulation in plant tissue however, relies on the era of the plant or tissue type. 


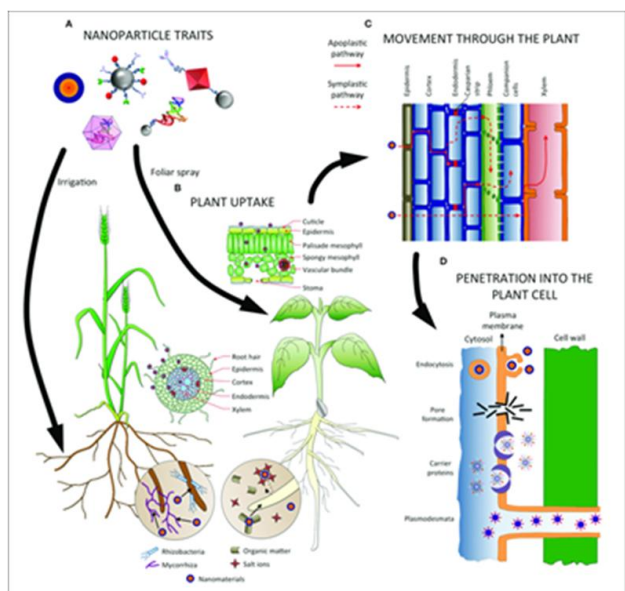

Fig. 8: Illustrates factors influencing absorption, uptake, transport and penetration of nanoparticles in plants.

(A) Nanoparticle are up taken and translocated in the plant, as well as the application method.

(B) In soil, nanoparticles can interact with microorganisms and compounds, which facilitate or hamper their absorption. Several tissues (epidermis, endodermis...) and barriers (Casparian strip, cuticle...) must be crossed before reaching the vascular tissues, depending on the entry point (roots or leaves).

(C) Nanomaterials can follow the apoplastic and/or the symplastic pathways for moving up and down the plant, and radial movement for changing from one pathway to the other.

(D) Several mechanisms have been proposed for internalization of nanoparticles inside the cells, such as endocytosis, pore formation, mediated by carrier proteins, and through plasmodesmata.

Alejandro Pérez-de-Luque (2017), plant uptake of nanoparticles is affected by several factors related to the nature of the nanoparticle itself, but also with the plant physiology and the interaction of the nanomaterials with the environment Fig. (8). It is clear that nanoparticle traits will greatly influence its behavior, and hence if the plant will be able to absorb it. Size seems to be one of the main restrictions for penetration into plant tissues, and there are some reports about the maximum dimensions that plants allow for nanoparticles to move and accumulate inside the cells, usually with 40-50 nm as a size exclusion limit (González-Melendi et al., 2008; Corredor et al., 2009; Sabo-Attwood et al., 2012; Taylor et al., 2014). Additionally, the type of nanoparticle and its chemical composition is another factor influencing the uptake Ma et al., (2010); Rico et al., (2011), whereas morphology has also been demonstrated as determinant in some cases (Raliya et al., 2016). Functionalization and coating of the nanomaterial surface can greatly change and alter the properties for its absorption and accumulation by the plant (Judy et al., 2012). Plant species can differ in their physiology, and such differences result in variations regarding uptake of nanoparticles, as reported for example by Cifuentes et al. (2010), Larue et al. (2012) and Zhu et al. (2012). These works showed how crops species belonging to different botanical families, and exposed to either magnetic carbon-coated, titanium dioxide or gold nanoparticles respectively, presented diverse absorption and accumulation patterns inside the plants. Nevertheless, the ways of application are also crucial in order to determine how effectively a plant will internalize the nanomaterials: roots are specialized in absorption of nutrients and water, whereas Schwab et al. (2015) reported that leaves are developed for gas exchange and present a cuticle that hampers penetration of substances. Nevertheless, nanoparticles interact with other components of the environment, and it can affect their properties and their traits for being assimilated by plants. For example, humic acids and other organic matter present in the soil can lead to an improved stability and hence a better bioavailability of nanomaterials, whereas salt ions might induce precipitation and trigger a contrary effect (Navarro et al., 2008). Even more, the presence of other organisms, such as bacteria and fungi, influences the plant uptake of nanoparticles, mainly if those microorganisms establish symbiosis with plants as in the case of mycorrhizal fungi (Feng et al., 2013; Wang et al., 2016)

Konstantopoulo et al. (2010) stated that in younger tissue or freshly growing leaves, nitrate accumulation less than mature leaves. Similarly observation, were noticed by Anjana and Iqbal (2007), collected tissues at the later level of vegetation have an elevated concentration of nitrate than those harvested at the younger level. Some plant families such as (Amaranthaceae, Asteraceae, Apiaceae, 
and Brassicaceae) are nitrate hyper-accumulators, while other species Lamiaceae are lower accumulators Santamaria (2006). On the other hand, fruits are found to possess less nitrate, $15 \mathrm{mg} \mathrm{kg}^{-1}$ $\mathrm{FW}^{-1}$ (Susin et al., 2006).

\subsection{Nitrate accumulation through nutrition and genetic aspects}

Uptake and accumulation of nitrate, gradually depends on field management, agricultural practices, environmental factors, genetic variability and availability of other nutrients, applied in the field. However, light intensity, nitrogen fertilizer application, and genetic variability are the key aspects influencing nitrate uptake and its successive accumulation in different plant species, especially in vegetables Santamaria (2006). The level of nitrate uptake and accumulation varies in different plant species Razgallah et al. (2017), genotypes diverse ploidy level Harada et al. (2003) and even in cultivars of the same plant species M'hamdi et al. (2016). Genetic variation in nitrate uptake exists among modern crop varieties Barraclough et al. (2014); Cormier et al. (2013), much wider range of these variations found in varieties, which has diverse germplasm base (Monostori et al., 2017).

However, total $\mathrm{N}$ uptake and high biomass/yield potential at low $\mathrm{N}$ availability are indicator for efficient $\mathrm{N}$ uptake genotypes (Hawkesford and Griffiths, 2019). Although, dwarfing genes improve harvest index and decrease susceptibility to lodging at higher $\mathrm{N}$ fertilizer doses in cereals (Gooding et al. 2012) but negative consequences of these genes appeared in the form of pleiotropic effects and decreased root proliferation in dwarf genotypes (Bai et al., 2013; Gooding et al. 2012). Variation in root proliferation, architecture, and function found to contribute nitrate uptake efficiency Allard et al. (2013). Higher nitrate accumulation demonstrates enhanced expression of nitrate transporter genes Harrison et al. (2004). Low-nitrate cultivars have an effective method of $\mathrm{N}$ transformation than crop species accumulating elevated nitrate. To preserve plant nitrate homeostasis, a favorable linear connection occurs between plant nitrate and water content (Qiu et al. 2014). Low nitrate accumulating cultivars have been found to have lower transcripts of the nitrate transporter gene (LsNRT) than high accumulators of nitrate do. Variation of plants in nitrate accumulation is guided by variations in nitrate absorption and assimilation through a method of chemical decrease (Luo et al. 2006). Nitrate from the rhizosphere gets entered the plant roots through absorption mediated by high and low-affinity nitrate transport channels (Fan et al. 2017).

The influx of nitrate is further increased by mobilization of absorbed nitrates to different plant tissues through xylem vessels by plant transpiration streaming process due to hydrostatic pressure gradient in the xylem vessels caused by transpiration at leaf surface Tyree (2003). Excessive use of $\mathrm{N}$ fertilizer results in greater absorption of nitrate, leading to the accumulation of nitrate in different plant tissues (Soleymani and Shahrajabian, 2012). Injudicious use of nitrogen fertilizer improves manufacturing costs, leads crop nitrate levels to rise and water quality to deteriorate when nitrate is leached to groundwater (Ahmed et al., 2017). As the plant grows towards maturity, demand for nitrogen declines, leading to nitrate accumulation due to excessive fertilization at the subsequent growth point. Hence, an efficient approach to decrease nitrate content in field produce is to give the crop a few days/weeks before harvest, which helps to deprive nitrate content.

\subsection{Consequences of different kind of fertilizers in nitrate accumulation}

The type of $\mathrm{N}$-fertilizer in the edible components of the plants is immediately linked to nitrate accumulation (Pavlou et al., (2007). Nitrogen exists as ammonium, nitrate, urea, or as organic compounds. Using ammonium-based nitrogen fertilizers reduces nitrate content in crop plants while applying nitrate-based fertilizer increases nitrate absorption (Wang and Li, 2004).

Thus, selective application of fertilizer may lead to the accumulation of nitrate in edible components of plants (Zhou et al., 2000). The nitrate accumulation in petioles exists in the order: urea $>$ ammonium nitrate $>$ ammonium sulfate $>$ ammonium carbonate (Renseigné et al. (2007). The release of $\mathrm{N}$ from inorganic fertilizer is much faster than that from natural sources because it occurs through mineralization of organic matter in the later one slow release (Herencia et al., 2011). In the organic fields, scientists noted considerably less nitrate content than conventionally grown plant crops applied with inorganic fertilization (Nunez de Gonzalez et al., 2015. Plants not only take essential nutrients from the soil, but also change the physico-chemical and biological properties of the soil as well, e.g., $\mathrm{pH}$, soil texture, electrical conductivity, and organic matter, the capacity of cation exchange, activity, and quantity of soil microbes (Bell and Dell 2008). Inorganic N fertilizer input is provided for 
sustainable crop production, but their higher doses are affecting soil properties and consequently reducing crop yields over time (Hepperly et al., 2009).

However, organic fertilizers help in maintaining the soil properties such as reducing soil bulk density, improving soil structure Mahmoodabadi et al. (2010), increasing water holding capacity of the soil, rising $\mathrm{pH}$ in acidic soils, hydraulic conductivity, and filtration rate (Purbajanti et al., 2019). Hence, the integrated approach of organic fertilizers with the limited and slow release of inorganic fertilizer application may prove to be a sustainable method for efficient nutrient utilization, less nitrate accumulation and to restore important soil properties (Schoebitz and Vidal, 2016). Organic manure will improve the physiochemical and biological properties of the soil; whereas, the slow release of inorganic material will help to meet the needs of crop plants instantly (Prasetyo et al., 2013). The use of conventional inorganic fertilizers is not suitable to sustain crop productivity due to higher inefficiency, delivery, utilization, the input of water, energy, and greater impact of negative environmental implications. The goal of global and safer food security can be achieved by modifying agricultural practices to combat negative pressure aroused from increasing population, climate change, and decreasing the area of arable land. Many nano-enabled fertilizers and engineered nanomaterials (ENMs) are reported to potentially enhance plant growth and increase crop productivity (Adisa et al., 2019). However, the knowledge of basic mechanistic processes involved in the functioning of nanofertilizers is lacking now. Nanofertilizers are engineered nanomaterials that enhance the availability, uptake, performance, and utilization of conventional fertilizers upon application (Liu and Lal, 2015). In many studies, nanofertilizers have been shown to improve food safety and enhance plant yield by foliar and soil applications (Dimkpa and Bindraban 2017; Chhipa 2017). For the last few decades, the nutrient use efficiency of most of the crop plants remained stagnant between 18 and 40\% Subramanian et al. (2015) due to inefficient nutrient delivery and plant's inherent ability to uptake, consequently leading environmental contamination by surface run-off, emission, and leaching. Several reports indicated the potential of nano-enabled fertilizers to enhance nutrient delivery, decrease nutrient immobilization, increase uptake efficiencies by plants, decreasing agricultural waste, and reducing.

Nanofertilizers potential could have dramatic environmental and economic impacts (Subramanian et al., 2015). The supply of other nutrients such as phosphorus (P), calcium (Ca), sulfur $(\mathrm{S})$, potassium $(\mathrm{K})$, magnesium $(\mathrm{Mg})$, molybdenum $(\mathrm{Mo})$, and iron $(\mathrm{Fe})$ may influence the accumulation of nitrate in plant crops as well as nitrogen. The plant's absorption of nitrate is positively related to the supply of P in soil Buwalda and Warmenhoven (1999) while negative to the supply of sulfate in soil (Blom-Zandstra and Lampe, 1983). On the other side, in the plant, $\mathrm{K}$ encourages nitrate absorption, remobilization, and assimilation (Ahmed et al., 2000). The role of Ca in root growth is well-documented and nitrate uptake may be affected by its deficiency. $\mathrm{Mg}$ is generally needed for the growth of chloroplast and metabolic processes (Borgognone et al., 2016). but there is no proof of its role in nitrate accumulation. Chloride and nitrate in soil have shown antagonism in osmo-regulation; therefore, the supply of chloride in high-nitrate cultivars may assist to decrease nitrate content (Borgognone et al., 2016). Mo has a specified position in the activity of nitrate reductase, which in its assimilation process converts nitrate to nitrite. In crops cultivated on soil with Mo deficiency, high nitrate content accumulates (Buwalda and Warmenhoven, 1999)

\subsection{Environmental factor for nitrate accumulation}

Several environmental factors influence nitrate accumulation in plants, such as the interaction of available nitrogen, temperature, and light intensity has been revealed to manipulate nitrate accumulation in certain plant species. Enhanced $\mathrm{N}$ fertilizer supply to plants under high light intensity increases the temperature that in turn promotes nitrate accumulation Santamaria et al. (2001) Fig. (9).

Zhonghua Bian et al. (2020) stated that nitrate assimilation in plants starts with the reduction of nitrate to nitrite by NR in the cytoplasm. The resulting nitrite is reduced to ammonium by nitrite reductase (NiR) localized in chloroplasts or in plastids in the roots Wang, and Tsay (2011) Fig. (9). Light is one of the main factors regulating plant growth and development Fig. (9), as light not only provides energy for driving photosynthesis but also serves as a transduction signal for triggering the expression of related genes. 

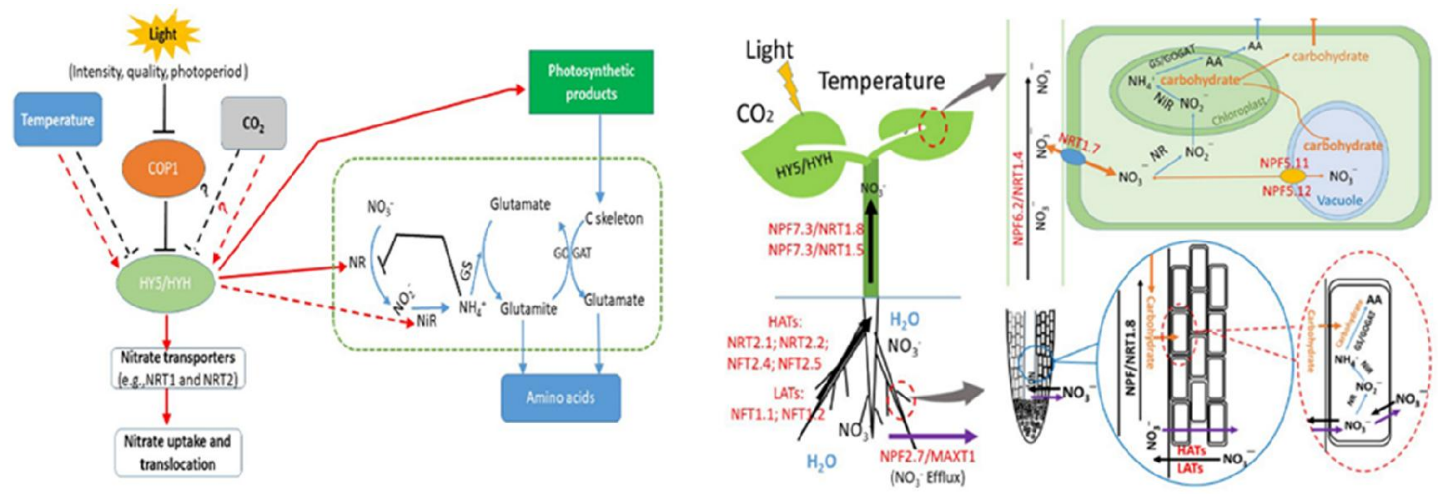

Fig. 9: Schematic representation of nitrate absorption, distribution, and assimilation in plants and the function of environmental factors that regulate of nitrate absorption and assimilation in plants.

Light stimulates nitrate reduction by inducing NR-related gene $(N R)$ expression, increasing NR activity, and providing available reductants (Iglesias-Bartolomé et al., (2004). In plant leaves, the reductants used for nitrate assimilation are produced from photosynthetic electron transport Busch et al. (2018), whereas in the roots, these reductants stem from the process of mitochondrial respiration and the pathways of malate and pentose phosphate (Ruan et al., 2010). After being received by the photosynthetic antenna complex in plant leaves, the absorbed light energy is transferred and stored as ATP and NADPH by the electron and proton transfer complex. Apart from primarily being used for carbon dioxide $\left(\mathrm{CO}_{2}\right)$ fixation, approximately $25 \%$ of the resulting ATP and NADPH will be used for nitrate assimilation in plants (Miller et al., 2007; Walker et al., 2014). Thus, excessive accumulation of nitrates in plant tissues frequently occurs under poor light conditions (Gruda, (2005). Supplementary light by artificial light sources is widely used to regulate plant growth, phytochemical concentrations, and nitrate concentration in vegetables produced in controlled environments (Bian et al., 2014; Bian et al., 2018; Lin et al., 2013).

Following the rapid development of light-emitting diode (LED) technology, LEDs have become a viable and innovative alternative to conventional horticultural lighting because LEDs offer unique advantages such as a high energy-use efficiency, long lifespan (approximately 10,000 h), lower heatput, and flexible spectral control Bian et al. (2016), The application of LEDs as either a sole source of lighting (e.g., closed-type plant factories and growth chambers) or as supplemental lighting, whether alone or mixed with conventional light sources (e.g., fluorescent and high-pressure sodium lamps), enables horticulturists and farmers to regulate the nitrate concentration in vegetables through light condition management in protected facilities Bian et al. (2016). In general, the effects of light on the uptake, assimilation, and distribution of nitrates can be categorized as related to light intensity, duration, or spectra Fig. (9).

Otherwise, diurnal changes in light intensity are inversely related to plant nitrate accumulation, as light intensity is involved in photosynthesis, plant nitrate uptake, reduction, and translocation of nitrate. By selecting suitable harvest time, the diurnal variation in nitrate accumulation can be held to a minimum level (Anjana et al., 2007). Weather conditions affect the plant nitrate content more drastically than by the source (organic or inorganic) and the rate of nitrogen fertilizer (Custic et al., 2003). Less nitrate content was observed in the year with high rainfall (Grzebelus and Baranski, 2001). Conversely, drought stress stimulates root nitrate uptake and shoot mobilization (Talouizite and Champigny, 1988). Higher plant nitrate accumulation was observed in autumn-winter as compared with the spring season (Santamaria et al., (1999). Nitrate/chloride ions, however, are interchangeable in osmo-regulation under salt stress; therefore, mild saline stress helps to prevent soil or soil-free nitrate accumulation. Nitrate is involved in the plant's high and low-affinity transport scheme because this method needs biochemical power (Bose and Srivastava, 2001). Consequently, the concentration of carbon dioxide, light intensity, and temperature of air impact the accumulation of nitrate in plant crops (Santamaria, 2006). Nitrate assimilation in the plant causes a photosynthesis process that offers carbon skeleton essential for ammonium inclusion (from nitrate decrease) and electrons release, which is discovered to be vital for nitrate conversion to nitrite (Cavaiuolo and Ferrante, 2014). Intensive N 
application and low light intensity result in greater accumulation of nitrate Fu et al. (2017), while elevated light spectrum decreases plant accumulation (Liu et al., 2016).

\section{Fertigation management techniques \\ 5.1. Plant monitoring}

Using plant as crop monitoring through different analytical aspects, in order to evaluate plant nutrient status and finally to correct nutrient delivery in terms of both quantity and type of nutrients. Such plant testing approach is based on the principle that the control of growing conditions should be based on the physiological status of the plant Nishina, (2015).To accelerate and accomplish the goal, both direct and indirect measurements of the nutrient status in plant tissues can be carried out in the field. Over the past 20 years, Thompson et al. (2017) stated that such technique has investigated particularly in terms of nitrogen nutrition due to its role in plant metabolism and for the environmental implications derived from nitrogen fertilizers when intensive applied. The main characteristics of this method are the ease and rapidity of the measurement, which allow for a sufficient number of measurements to obtain crop-representative data. The first testing technique to be developed was petiole sap analysis, which is probably still the most common aspect. Sap extraction analysis from a leaf petiole was still used in many studies, for monitoring plant nutritional status and eventually optimizing plant fertilization.

A significant correlation between $\mathrm{NO}^{-3}$ and $\mathrm{K}$ concentration in petiole sap and $\mathrm{N}$ or $\mathrm{K}$ content in plant tissues has been observed for many vegetable crops (Goffart et al., 2008; Farneselli et al., 2014), Peña-Fleitas et al., 2015). However, such technique, has disadvantages since the values of nutrient concentration in the leaf petiole sap change as a function of (i) crop stage values of sufficiency decline with crop age) ; (ii) cultivation system; (iii) species and cultivar and (iv) plant nutrient and water status (Goffart et al. (2008). However, reference values for $\mathrm{N}$ and $\mathrm{K}$ are available for different types of vegetables grown in Florida Hochmuth, (1994) efficiency for melon and tomato in Almeria (Spain) Peña-Fleitas etal (2015), for potatoes in central and northern Europe Goffart et al. (2008), and for industrial tomato production in central Italy (Farneselli et al., 2014). Most promising technologies for rapidly plant monitoring are optical sensors. Tissue (leaf) chlorophyll fluorescence, reflectance, and transmittance can be measured and obtaining crop indices that can be correlated with plant stress and nutrient status (Muñoz-Huerta et al., 2013). The optical measuring devices can be divided into sensors able to measure portions of a plant or individual leaves and those able to acquire data from large parts of the canopy, and that could be installed on tractors, drones, robots, or even on airplanes or satellites. Among the portable instruments, the most widely used are the chlorophyll meter SPAD-502 (based on single-photon avalanche diode (SPAD) technology), originally developed by Konica-Minolta (Osaka, Japan), the Hydro N-tester (Yara International, Oslo, Norway) and Dualex Scientific+® (FORCE-A, Paris, France). The SPAD produces a dimensionless index positively correlated to the concentration of chlorophyll in the leaf blade, which is in turn related to the concentration of $\mathrm{N}$ in plant tissues. Once the values of $\mathrm{N}$ sufficiency are assessed, the corresponding SPAD index value can be used to support $\mathrm{N}$ fertilization (Muñoz-Huerta et al., 2013; Padilla et al., 2015).

Some authors have found variability in the SPAD index when the culture was carried out in the presence of abiotic stress (Swiader et al., 2002). SPAD measurement variability can be reduced after in-situ calibration of the instrument (e.g., non-fertilized parcel), as, for example, recommended by the manufacturers of some chlorophyll meters (i.e., N Tester ${ }^{\circledR}$ Yara, Yara International, Oslo, Norway). The variability of the SPAD index and the need to calibrate it for each species, cultivation conditions, etc., are the major reasons why, despite the fact that the first experiments occurred more than 20 years ago, commercial use for the management of fertilization has up until now been quite limited. A new promising instrument is the Dualex Scientific $+\circledR$ (FORCE-A, Paris, France). The Dualex $₫$ can provide four different indices related to the concentration of chlorophyll, flavonols, anthocyanins and $\mathrm{N}$ derived by the nitrogen balance index $(\mathrm{NBI} \Re)$; it can be used to assess the nutritional status of the crop and the presence of stress (Goulas et al. 2004). Tremblay et al. (2009) reported that, $\mathrm{N}$ fertilization of winter vegetable crops in the open field, have used The Dualex ${ }^{\circledR}$ successfully. The authors also observed a high correlation between the indices obtained with the Dualex ${ }^{\circledR}$, the SPAD and nitrate concentrations in the leaf petioles. Wu et al. (2007) evaluated the effectiveness of various methods to manage the $\mathrm{N}$ nutrition of potatoes by comparing the SPAD index, the analysis of the leaf petiole sap and use of images acquired by Quick Bird satellite with different types of spectral resolution for the calculation of 
the normalized difference vegetative index (NDVI). The best results were provided by the analysis of the petiole sap followed by SPAD, while information derived from satellite images were of little value for the practical management of the $\mathrm{N}$ fertilization. Muñoz-Huerta et al. (2013) published a review work summarizing the characteristics of optical sensors, including those based on the measurements of tissue reflectance.

These types of sensors can be divided into two main categories: (i) those that measure the reflectance of the canopy through a multispectral sensor dependent on passive sunlight, such as CropScan ${ }^{\circledR}$ (Cropscan, Rochester, NE, USA) and FieldSpec ${ }^{\circledR}$ (ASD PANalytical, Boulder, CO, USA); (ii) those that measure reflectance by producing the source light themselves, thereby providing a more precise measurement independent of the ambient light, such as N Sensor ${ }^{\mathrm{TM}}$ (Yara, Grimsby, UK), Crop Circle ${ }^{\circledR}$ (Holland Scientific, Lincoln, The Netherlands), and GreenSeeker ${ }^{\circledR}$ (Trimble, Sunnyvale, CA, USA). Most research on reflectance meters has been conducted with cereal crops, although some studies are available for vegetable crops (Padilla et al., 2015; Gianquinto et al., 2011; Padilla et al., 2014). The use of multispectral images for estimating the nutrient content of the canopy and nutrient supply management have been assessed in many reports (Baret et al., 2007; Usha, and Singh 2013). Canopy reflectance measurements are based on the relationships between visible and near infrared (NIR) wavelengths and the crop canopy status (Fox and Walthall, 2008; Samborski et al., 2009). The reflectance value of specific wavelengths can be used in the computation of different indices, of which the NDVI is the most common (Muñoz-Huerta et al., 2013). Indices related to healthy and stressed crops can be compared for the interpretation of collected data. Finally, this approach improves fertilization management, has applied in extensive cropping systems, where the growing cycles are relatively long and the growers have enough time to correct mineral fertilization if necessary. On the other hand, this methods of analysis cannot used successfully in vegetable which has short growing cycles (20-40 days) such as salad vegetables and radish crops.

\subsection{Root zone monitoring}

Soil testing to monitor nutrient availability in the root zone is a valuable alternative to plant monitoring. Fertigation can be modulated as a function of a target (i.e., optimal) concentration or quantity per soil volume of fertilizer, to be maintained in the root zone and to achieve optimal yield and quality for the crop. Nutrient availability particularly in root zone can be used for monitoring techniques. (i) Analytical analysis in which nutrients are extracted by solutions containing barium chloride, ammonium acetate and calcium chloride, for example; (ii) analysis of soil or substrate aqueous extract (e.g., 1:2 V:V soil /water; as described by Sonneveld, and Voogt, (2009), and (iii) analysis of soil water solution extracted from the root zone by suction lysimeters (Granados et al., 2013). Detailed data of laboratory analyses of soil samples are more useful for pre-transplant fertilization and for the evaluation of nutrient availability in the medium-long period, for quick adjustments of fertigation particularly, during the cultivation period using aqueous extracts appears to be more effective and accurate (Thompson et al., 2017). Over the last 20 years, corrective fertilization protocols for many greenhouse, based on the chemical analysis of extracts $(1: 2 \mathrm{~V}: \mathrm{V})$ have been developed. Samples were analyzed for nutrients from the root zone that collected each 3-6 weeks, depending on the crops. The nutrient solution can be adjusted after comparing analyzed values with pre-established thresholds, (Sonneveld and Voogt, 2009; Van den Bos et al., 1999).

The frequent nutrient addition with low water volume supplied by fertigation means that the concentration of nutrients in the aqueous extract is highly representative of the root zone nutrient status. Method can applied for monitoring saline (ballast) ions (Hartz et al., 1996). Na, Cl or simply EC. Suction lysimeters allow an easy sampling of the soil solution in the root zone. This consists of a porous cup hermetically welded on a pipe into which a capillary is inserted. The capillary enables the collection of the circulating solution extracted from the soil after applying a vacuum (maintained for 24-36 h after the end of irrigation), using a pump or a simple syringe. The method has been widely investigated in Israel, Spain and Australia and has been found effective for the management of $\mathrm{N}$ in greenhouse crops. However, the uncertainty, measurements, due to the large spatial variation of the soil nutrient content, is a weak point that limits the commercial use of this technique (Granados et al., 2013). For example, Hartz and Hochmuth Hartz proposed using them in vegetable crops with a threshold value of $5 \mathrm{mmol}$ $\mathrm{L}^{-1}$. Hartz (2003) later concluded that errors due to the high spatial variability of the soil solution might limit their application. Experimental work on tomatoes and melons has been carried out in protected 
cultivation but revealed a poor correlation between the nutritional status of the plant and the concentration of nutrients in the suction cup extract; the method therefore appears to be more suitable when excesses are avoided (Peña-Fleitas et al., 2015). The aqueous extract obtained through different methods can be analyzed with a rapid determination kit and other analysis tools (Thompson et al., 2009, 2013; Parks et al., 2012).

Several rapid chemical analysis systems are on the market that can be used to monitor the concentration of nutrients in water extracts, but the most effective are based on the use of photometry with visible light and ion-specific sensors such as ion selective optodes (ISO), ion selective electrodes (ISE), and ion-selective field effect transistors (ISFEs). There are many simple and portable photometers available (e.g., RQ Reflectoquant Flex ${ }^{\mathrm{TM}}$, Merck KGaA, Darmstadt, Germany) and several rapid kits based on color reactions. Undoubtedly, ion-specific sensors based on optical (ISO) or electrochemical (ISE or ISFET) reactions are particularly suitable for the fertigation of soilless crops where the nutrient solution can be easily collected (Bamsey et al., 2012). Commercial examples of portable specific ion sensors are CardyNO3 Meter ${ }^{\mathrm{TM}}$, (Horiba Ltd., and Kyoto, Japan) for the determination of NO3-, and the Nutrient Analyzer ${ }^{\mathrm{TM}}$ (Clean-grown, Wolver Hampton, United Kingdom) for the determination of N-NO3, N-NH4, Ca, Mg, K, Cl, Na, $\mathrm{P}^{\mathrm{H}}$ and EC. Some studies have recently proposed the use of NIR reflectance for the estimation of $\mathrm{N}$ and $\mathrm{P}$ content directly on the soil samples without extraction treatments (Bogrekci and Lee, 2005; Bansod et al., 2014). Here, the measurement is carried out through spectroscopes or instruments in which the light source is provided by LED lamps emitting monochromatic light at wavelengths in the absorption range of the investigated element. In the future, these sensors could potentially estimate different chemical elements in soil.

\subsection{Decision support system based on crop monitoring}

The extensive research activity conducted through plant monitoring to assess crop nutritional status; however, few applicative protocols have been developed based on this method. High variability of nutrient concentration in plant tissues and the need for knowledge of their respective critical thresholds, which may change as a function of cultivated species, plant/organ age, cultivation system and pedo-climatic conditions, may limit the application of this approach under a wide range of conditions, which is an important aspect when transferring technologies into practical operations. For the above reasons, most DSSs based on corrective approaches related to soil monitoring or data for both soil/plant monitoring methods. This approach was proposed by Goffart et al. (2011) with the CRA-W model; the DSS predicts the total nitrogen to be supplied as a function of expected yield and soil analysis, and $70 \%$ of the above quantity is given at transplant while the remaining $30 \%$ is supplied if necessary after evaluating plant status by rapid tissue analysis (e.g., using chlorophyll meters). The KNS (Kulturbegleitende Non-Sollwerte) method has been proposed for vegetable crops in Germany Lorenz et al. (1989), this DSS computes the $\mathrm{N}$ balance based on the assumption that a minimum nutrient buffer must be maintained in the root zone to ensure high yield and quality. KNS has been tested on 21 different vegetables with an average $\mathrm{N}$ reduction of $57 \%$ compared with standard growers' practice Ziegleretal (1996). An upgraded version of KNS is the N-Expert DSS Fellerand Fink (2002), However, the most popular approach based on Horticulturae 2017, 3, 3714 of 20 soil testing is probably the "Fertigation Model" Voogt et al. (2000) initially developed by Dutch researchers Sonneveld and Voogt (2009), Van den Bos et al. (1999) before being used across Europe. The method has been extensively adopted at the commercial level in the Netherlands Thompson et al. (2017) and by growers from Mediterranean countries such as Italy Incrocci, and Gestire (2003) and Greece (De Kreij et al., 2007). In Italy, the method can be applied with the user-friendly software GreenFert (Incrocci and Gestire, 2012)

\section{Conclusions}

Using fertigation through micro-irrigation systems is one of the most effective strategies to improve nutrient use efficiency in agricultural management techniques. The possibility of supplying nutrients elements at a low concentration rate with a high frequency may improve nutrient availability and furthermore, nutrient uptake by plant particularly in the root zone, besides, reducing risk of nutrient loss. Plant produce is the key form of dietary intake and source of nitrate consumption by human beings. Although nitrogen fertilizers are required for sustainable crop production to achieve food security, nitrogen efficiency of different crop plants ranges from 18 to $35 \%$, causing the wastage of inorganic 
fertilizers and has become a major source of nitrate contamination in the terrestrial and aquatic ecosystem. Various approaches have been discussed to keep plant nitrate accumulation and nitrate contamination in the environment to a minimal level.

The above aspects gradually influence the economic and environmental sustainability of agricultural activities. Under optimal management, techniques are followed, the application of fertigation allows for high yield and quality of agricultural produce, and high income for growers. Drip irrigation provides more crops per drop and it saves about $30-50 \%$ of water. Thus, a major increase in water use efficiency and reduction in land and water degradation is essential. All researches, studies and approaches showed that increasing water use efficiency in irrigated agriculture is inevitable considering climatic change, drought conditions and decreasing water resources. This could be achieved mainly by use of drip irrigation. In addition, fertilizers and chemicals can be applied in safe and desired concentrations. Taking into account fertigation and drip irrigation, both of them could markedly improve availability and absorption of water and nutrients in soil, resulting in substantial increase of crop production and quality. Design, management, operation and maintenance of drip irrigation and fertigation need much more data on soil and crops, and higher skills and experiences. If all these conditions are taken into consideration, the maximum benefit can be obtained by use of drip irrigation and fertigation.

Scientifically based criteria are adopted for determining the optimal type and application rate of fertilizers. The latter must be estimated because of objective methodologies that take into account all of the agricultural system variables that can interact with the fertilization process. New and accurate methodology are urgent required for supporting that theory. Many aspects have been developed to achieve the previous aims, besides; new techniques involving promising instruments will be available for management of fertigated crops.by all of each approach revised, still decision support systems based on simulation models and soil-testing approaches are the most common, nevertheless optical sensors have much potential to accommodate the foregoing tools for precise control fertigation in intensive cropping systems

\section{References}

Abalos, D., L. Sanchez-Martin, L. Garcia-Torres, J.W. van Groenigen, and A. Vallejo, 2014. Management of irrigation frequency and nitrogen fertilization to mitigate GHG and NO emissions from drip-fertigated crops. Sci. Total Environ., 490: 880-888. [CrossRef] [PubMed]

Addiscott, T.M., A.P. Withmore, and D.S. Powlson, 1991. Farming, fertilisers and the nitrate problem, CAB International, Wallingford, UK. Li S.X., Wang Z.H., Hu T.T., Gao Y.J., Stewart B.A., 2009. Chapter 3. Nitrogen in Dryland Soils of China and Its Management, in: Sparks D.L. (Ed.), Advances in Agronomy): 123-181.

Adisa, I.O., L.R.P. Venkata, R.P. V. Jose, O.D. Christian, H.E. Wade, L.G.-T. Jorge and C.W. Jason, 2019. Recent advances in nano-enabled fertilizers and pesticides: a critical review of mechanisms of action, Environ. Sci.: Nano, 6: 2002-2030

Adisa, I.O., V.L.R. Pullagurala, J.R. Peralta-Videa, C.O. Dimkpa, W.H. Elmer, J.L. Gardea-Torresdey, and J.C. White, 2019. Recent advances in nanoenabled fertilizers and pesticides: A critical review of mechanisms of action. Environ Sci: Nano 6:2002-2030

Agostini, F., F. Tei, M. Silgram, M. Farneselli, P. Benincasa, and M. Aller, 2010. Decreasing nitrate leaching in vegetable crops with better N management. In Genetic Engineering, Biofertilisation, Soil Quality and Organic Farming; Springer: Berlin, Germany, 147-200.

Ahmed A.H.H., M.K. Khalil, and A.M. Farrag, 2000. Nitrate accumulation, growth, yield and chemical composition of Rocket (Eruca vesicaria subsp. sativa) plant as affected by NPK fertilization, kinetin and salicylic acid, in: Proceedings of ICEHM 2000, Cairo University, Egypt, 495-508.

Ahmed, M., M. Rauf, Z. Mukhtar, and N.A. Saeed, 2017. Excessive use of nitrogenous fertilizers: an unawareness causing serious threats to environment and human health. Environ. Sci. Pollut. Res., 24:26983-26987

Alejandro, P.D.L., 2017. Interaction of Nanomaterials with plants, What do we need for real application in agriculture, Environ. Sci.do, 10, 3389 fenvs., 1-17. 
Allard, V., P. Martre, and J. Le Gouis, 2013. Genetic variability in biomass allocation to roots in wheat is mainly related to crop tillering dynamics and nitrogen status. Eur. J. Agron. 46:68-76

Alvino, A., and S. Marino, 2017. Remote and proximal sensing for precision agriculture and irrigation management.Horticulturae, inpress.

Andrews, M., J.A. Raven, and P.J. Lea, 2013. Do plants need nitrate? The mechanisms by which nitrogen form affects plants. Ann. Appl. Biol. 163: 174-199

Anjana, Sh. U., and I. Muhammad, 2007. Nitrate accumulation in plants, factors affecting the process, and human health implications. A review, Agron. Sustain. Dev. 27, 45-57

Anonymous, 2019a. Water and agriculture. [online], cit. [2019- 08-10]. Available at: https://blogs.worldbank.org/opendata/ chart-globally-70-freshwater-used agriculture

Asseng S., W. Cao, W. Zhang, and F. Ludwig, 2009. Crop physiology, Modelling and Climate Change: Impact and Adaptation Strategies, in: Sadras V.O., Calderini D.F. (Eds.), Crop Physiology, Academic Press, Amsterdam, 511-545.

Aujla, M.S., H.S. Thind and G.S. Buttar, 2006. Fruit yield and water use efficiency of eggplant (Solanum melongena L.) as influenced by different quantities of nitrogen and water applied through drip and furrow irrigation. Sci. Hort.,112:142-148.

Ayars, J.E., C.J. Phene, R.B. Hutmacher, K.R. Davis, R.A. Schoneman, S.S. Vail, and R.M. Mead, 1999. Subsurface drip irrigation of row crops: A review of 15 years of research at the Water Management Research Laboratory. Agr. Water Mgt., 42:1-27.

Badr, M., and A. El-Yazied, 2007. Effect of fertigation frequency from subsurface drip irrigation on tomato yield grown on sandy soil. Aust. J. Basic Appl. Sci., 1: 279-285.

Bai, C.H., Y.L. Liang, and M.J. Hawkesford, 2013. Identification of QTLs associated with seedling root traits and their correlation with plant height in wheat. J. Exp. Bot. 64:1745-1753

Bamsey, M., T. Graham, C. Thompson, A. Berinstain, A. Scott, and M. Dixon, 2012. Ion-specific nutrient management in closed systems: The necessity for ion-selective sensors in terrestrial and space-based agriculture and water management systems. Sensors, 12: 13349-13392. [CrossRef] [PubMed]

Bansod, S.J., and S.S. Thakare, 2014. Near Infrared spectroscopy based a portable soil nitrogen detector design. Int. J. Comput. Sci. Inf. Technol., 5, 3953-3956.

Baret, F., V. Houlès, and M. Guérif, 2007. Quantification of plant stress using remote sensing observations and crop models: The case of nitrogen management. J. Exp. Bot., 58: 869-880. [CrossRef] [PubMed]

Barraclough, P.B., R. Lopez-Bellido, and M.J. Hawkesford, 2014. Genotypic variation in the uptake, partitioning and remobilisation of nitrogen during grain-filling in wheat. Field Crops Res 156:242-248.

Barua, S., R. Kumar, and S.P. Singh, 2018. Water saving techniques in agriculture. [online], cit. [201903-19]. Available at: https://www. indiawaterportal.org/articles

Bar-Yosef, B., 1999. Advances in fertigation. In Advances in Agronomy; Sparks, D.L., Ed., Academic Press: London, UK. 65: 1-77.

Bell, R.W. and B. Dell, 2008. Micronutrients for sustainable food, feed, Fiber and bioenergy production, 1 st edn. IFA, Paris, pp 1-195

Bian, Z.H., R.C. Cheng, Y. Wang, Q.C. Yang and C.G. Lu, 2018. Effect of green light on nitrate reduction and edible quality of hydroponically grown lettuce (Lactuca sativa L.) under short-term continuous light from red and blue light-emitting diodes. Environ. Exp. Bot., 153, 6371. [CrossRef]

Bian, Z.H., R.F. Cheng, Q.C. Yang, J. Wang, and C.G. Lu, 2016. Continuous light from red, blue, and green light-emitting diodes reduces nitrate concentration and enhances phytochemical concentrations and antioxidant capacity in lettuce. J. Am. Soc. Hortic. Sci., 141: 186- 195. [CrossRef]

Blom-Zandstra, M., and J.E.M. Lampe, 1983. The effect of chloride nitrate-N is assimilated into amino acids, and a vacuolar and sulphate salts on the nitrate content in lettuce plants storage pool in which nitrate is not metabolized. The (Lactuca sativa L.). Journal of Plant Nutrition, 6: 611-628.

Bogrekci, I., and W.S. Lee, 2005. Spectral measurement of common soil phosphates. Trans. ASAE, 48, 2371-2378. [CrossRef] 
Borgognone, D., G. Colla, Y. Rouphael, M. Cardarelli, E. Rea, and D. Schwarz, 2013. Effect of nitrogen form and nutrient solution $\mathrm{pH}$ on growth and mineral composition of self-grafted and grafted tomatoes. Sci. Hort. 149:61-69.

Borgognone, D., Y. Rouphael, M. Cardarelli, L. Lucini, and G. Colla, 2016. Changes in biomass, mineral composition, and quality of cardoon in response to $\mathrm{NO}_{3}{ }^{-}$: cl- ratio and nitrate deprivation from the nutrient solution. Front Plant Sci., 7:978.

Bryan, B.B. and E.L. Thomas, 1958. Distribution of Fertilizer Materials Applied through Sprinkler Irrigation Systems; Arkansas System Division of Agriculture Experiment Station: Fayetteville, AR, USA, 12.

Burns, I.G., K. Zhang, M.K. Turner, M. Meacham, K. Al-Redhiman, J. Lynn, M.R. Bradley, P. Hand, and D. Pink, 2011. Screening genotypes and environment effects on nitrate accumulation in 24 species of young lettuce. J. Sci. Food Agric., 91:553-562.

Burt, M.C., 1998. Fertigation Basics. Irrigation Training and Research Center (ITRC), ITRC Paper 98001. San Luis Obispo, CA, USA: California Polytechnic University.

Busch, F.A., R.F. Sage, and G.D. Farquhar, 2018. Plants increase CO2 uptake by assimilating nitrogen via the photorespiratory pathway. Nat. Plants, 4, 46. [CrossRef] [PubMed]

Buwalda, F., and W. Mary, 1999. Growth-limiting phosphate nutrition suppresses nitrate accumulation in greenhouse lettuce. Journal of Experimental Botany, 50(335): 813-821

Causton, D.R. and P.M. Dale, 1990. The monomolecular and rectangular hyperbola as empirical models of the response of photosynthetic rate to photon flux density, with applications to three Veronica species. Ann. Bot., 65: 389-394. [CrossRef]

Çetin, O. and D. Uygan, 2008. The effect of drip line spacing, irrigation regimes and planting geometries of tomato on yield, irrigation water use efficiency and net return. In Agric. Wate. Manage. 95(8): 949-958.

Çetin, O. and L. Bilgel, 2002. Effects of different irrigation methods on shedding and yield of cotton. In Agric. Wate. Manage, 54(1): 1-15.

Çetin, Ö., N. Üzen, M.G. Temiz, and S. Başbag, 2018. Comparison of surface and sub-surface drip irrigation and real-time irrigation scheduling based on FAO-56-Penman-Monteith for cotton. Final Project Report, Project No: TUBITAK 1150600, Ankara, Turkey (with an English abstract in Turkish).

Chartzoulakis, K. and M. Bertaki, 2015. Sustainable water management in agriculture under climate change. In Agriculture and Agricultural Science Procedia, (4): 88- 98.

Chen, B.M., Z.H. Wang, S.X. Li, G.X. Wang, H.X. Song, and X.N. Wang, 2004. Effects of nitrate supply on plant growth, nitrate accumulation, metabolic nitrate concentration and nitrate reductase activity in three leafy vegetables. Plant Sci. 167:635-643

Chen, Q., H. Zhang, X. Li, P. Christie, D. Horlacher, and H.P. Liebig, 2005. Use of a modified N-expert system for vegetable production in the Beijing region. J. Plant Nutr., 28: 475-487. [CrossRef]

Chhipa H., 2017. Nanofertilizers and nanopesticides for agriculture. Environ Chem Lett 15:15-22.

Cifuentes, Z., L. Custardoy, J. M. de la Fuente, C. Marquina, M. R. Ibarra, D. Rubiales, et al., 2010. Absorption and translocation to the aerial part of magnetic carbon-coated nanoparticles through the root of different crop plants. J. Nanobiotechnology 8:26. doi: 10.1186/1477-3155-8-26.

Colla G., R. Youssef, M. Cristina, and C. Mariateresa, 2011. Nitrogen-use efficiency traits of miniwatermelon in response to grafting and nitrogen fertilization doses, J. Plant Nutr. Soil Sci., 174, 933-941, DOI: 10.1002/jpln.201000325

Colla, G., Y. Rouphael, C. Mirabelli, and M. Cardarelli, 2011. Nitrogen-use efficiency traits of mini watermelon in response to grafting and nitrogen-fertilization doses. J Plant Nutr Soil Sci., 174:933-941.

Colonna, E., Y. Rouphael, G. Barbieri, and S. De Pascale, 2016. Nutritional quality of ten leafy vegetables harvested at two light intensities. Food Chem., 199:702-710.

Cormier, F., S. Faure, P. Dubreuil, E. Heumez, K. Beauchene, S. Lafarge, S. Praud, and J. Le Gouis, 2013. A multi-environmental study of recent breeding progress on nitrogen use efficiency in wheat (Triticum aestivum L.). Theor. Appl. Genet., 126:3035-3048

Corredor, E., P.S.Testillano, M. J. Coronado, P. González-Melendi, R. FernándezPacheco, C. I. Marquina, et al., 2009. Nanoparticle penetration and transport in living pumpkin plants: in situ subcellular identification. BMC Plant Biol. 9:45. doi: 10.1186/1471-2229-9 45. 
Custic, M., M. Poljak, L. Coga, T. Cosic, N. Toth, and M. Pecina, 2003. The influence of organic and mineral fertilization on nutrient status, nitrate accumulation, and yield of head chicory, Plant Soil Environ., 49: 218-222.

De Kreij, C., V. Kavvadias, A. Assimakopoulou, and A. Paraskevopoulos, 2007. Development of Fertigation for Trickle Irrigated Vegetables under Mediterranean Conditions. Int. J. Veg. Sci., 13: 81-99. [CrossRef]

Dimkpa, C.O., and P.S. Bindraban, 2017. Nanofertilizers: new products for the industry? J Agric. Food Chem. 66:6462-6473

Elia, A., and G. Conversa, 2015. A decision support system (GesCoN) for managing fertigation in open field vegetable crops. Part I-methodological approach and description of the software. Front. Plant Sci., 6: 1-18. [CrossRef] [PubMed]

Epstein, E., 1956. Mineral nutrition of plants: mechanism of uptake and transport. Annu Rev Plant Physiol. 7:1-24.

Everaarts, A.P., and C.P. de Moel, 1998. The effect of nitrogen and the method of application on yield and quality of white cabbage. Eur. J. Agric., 9: 203-211. [CrossRef].

Fan, X., M. Naz, X. Fan, W. Xuan, A.J. Miller, and X. Xu, 2017. Plant nitrate transporters: from gene function to application. J. Exp. Bot., 68:2463-2475.

Farneselli, M., F. Tei, and E. Simonne, 2014. Reliability of petiole sap test for n nutritional status assessing in processing tomato. J. Plant Nutr., 37: 270-278. [CrossRef]

Farneselli, M., P. Benincasa, G. Tosti, E. Simonne, M. Guiducci, and F. Tei, 2015. High Fertigation frequency improves nitrogen uptake and crop performance in processing tomato grown with high nitrogen and water supply. Agric. Water Manag., 154: 52-58. [CrossRef]

Feng, Y., X. Cui, S. He, G. Dong, M. Chen, J. Wang, et al., 2013. The role of metal nanoparticles in influencing arbuscular mycorrhizal fungi effects on plant growth. Environ. Sci. Technol., 47, 9496-9504. doi: 10.1021/es402109n

Fox, R.H., and C.L. Walthall, 2008. Crop monitoring technologies to assess nitrogen status. In Nitrogen in Agricultural Systems; American Society of Agronomy: Madison, WI, USA, 647-674.

Galloway, J.N., A.R. Townsend, J.W. Erisman, M. Bekunda, Z. Cai, J.R. Freney, L.A. Martinelli, S.P. Seitzinger and M.A. Sutton, 2008. Transformation of the Nitrogen Cycle: Recent Trends, Questions, and Potential Solutions, Science, 320: 889-892

Garwood E.A., and T.E. Williams, 1967. Growth, water use and nutrient uptake from the subsoil by grass swards, J. Agr. Sci., 69: 125-130.

Gaudreau, L., J. Charbonneau, L.P. Vezina, and A. Gosselin, 1995. Effects of photoperiod and photosynthetic photon flux on nitrate content and nitrate reductase activity in greenhouse-grown lettuce, J. Plant Nutr., 18:437-453.

George, R. 2017. Sensor sense in irrigation management. Horticulturae, submitted.

Gianquinto, G., F. Orsini, M. Fecondini, M. Mezzetti, P. Sambo, and S. Bona, 2011. A methodological approach for defining spectral indices for assessing tomato nitrogen status and yield. Eur. J. Agric., 35: 135-143. [CrossRef]

Giller, K.E., P. Chalk, A. Dobermann, L. Hammond, P. Heffer, J.K. Ladha, P. Nyamudeza, L. Maene, H. Ssali, and J. Freney, 2004. Emerging technologies to increase the efficiency of use of fertilizer nitrogen. In Agriculture and the Nitrogen Cycle; Mosier, A., Syers, J.K., Freney, J.R., Eds., Island Press: New York, NY, USA, 344.

Goffart, J.P., M. Olivier, and M. Frankinet, 2008. Potato Crop Nitrogen Status Assessment to Improve N Fertilization Management and Efficiency: Past-Present-Future. Potato Res., 51: 355-383. [CrossRef]

Goffart, J.P., M. Olivier, and M. Frankinet, 2011. Crop nitrogen status assessment tools in a decision support system for nitrogen fertilization management of potato crops. Horttechnology, 21: 282286.

Goldberg, D., B. Gornat, and D. Rimon, 1976. Drip Irrigation Principles, Design and Agricultural Practices; Drip Irrigation Scientific Publications: Kfar Shmariahu, Israel,

Gonzalez-Dugo V., J.L. Durand, F. Gastal, and C. Picon-Cochard, 2005. Short-term response of the nitrogen nutrition status of tall fescue and Italian ryegrass swards under water deficit, Aust. J. Agr. Res., 56: 1269-1276 
González-Melendi, P., R. Fernández-Pacheco, M. J. Coronado, E. Corredor, P. S. Testillano, M.C. Risueño, et al., 2008. Nanoparticles as smart treatment-delivery systems in plants: assessment of different techniques of microscopy for their visualisation in plant tissues. Ann. Bot., 101, 187195. doi: $10.1093 / \mathrm{aob} / \mathrm{mcm} 283$

González-Melendi, P., R. Fernández-Pacheco, M. J. Coronado, E. Corredor, P. S. Testillano, M. C. Risueño, et al., 2008. Nanoparticles as smart treatment-delivery systems in plants: assessment of different techniques of microscopy for their visualisation in plant tissues. Ann. Bot. 101, 187195. doi: $10.1093 / \mathrm{aob} / \mathrm{mcm} 283$

Gooding, M.J., M. Addisu, R.K. Uppal, J.W. Snape, and H.E. Jones, 2012. Effect of wheat dwarfing genes on nitrogen-use efficiency. J. Agric. Sci., 150: 3-22.

Goulas, Y., Z.G. Cerovic, A.Cartelat, and I. Moya, 2004. Dualex: A new instrument for field measurements of epidermal ultraviolet absorbance by chlorophyll fluorescence. Appl. Opt., 43: 4488-4496. [CrossRef] [PubMed]

Granados, M.R., R.B. Thompson, M.D. Fernández, C. Martínez-Gaitán, and M. Gallardo, 2013. Prescriptive-corrective nitrogen and irrigation management of fertigated and drip-irrigated vegetable crops using modeling and monitoring approaches. Agric. Water Manag., 119:121-134. [CrossRef]

Gruda, N., 2005. Impact of environmental factors on product quality of greenhouse vegetables for fresh consumption. Crit. Rev. Plant Sci., 24: 227-247. [CrossRef]

Hagin, J., and A. Lowengart, 1995. Fertigation for minimizing environmental pollution by fertilizers. Fert. Res., 43:5-7.[CrossRef]

Hagin, J., M. Sneh, and A. Lowengart-Aycicegi, 2003. Fertigation, Fertilization through Irrigation. International Potash Instituite, IPI Research Topics, Basel, Switzerland, 23.

Hansen, S., P. Abrahamsen, C.T. Petersen, and M. Styczen, 2012. Daisy: Model use, calibration, and validation. Trans. ASABE, 55, 1315-1333. [CrossRef]

Hanson, B.R., J. Šim $u^{\circ}$ nek, and J.W. Hopmans, 2006. Evaluation of urea-ammonium-nitrate fertigation with drip irrigation using numerical modeling. Agric. Water Manag., 86, 102 113.[CrossRef]

Harada H., Y. Yoshimura, Y. Sunaga, T. Hatanaka, and S. Sugita, 2003. Breeding of Italian ryegrass (Lolium multiflorum Lam.) for a low nitrate concentration by seedling test, Euphytica, 129: 201209.

Harada, H., Y. Yoshimura, Y. Sunaga, T. Hatanaka, and S. Sugita, 2003. Breeding of Italian ryegrass (Lolium multiflorum lam.) for a low nitrate concentration by seedling test. Euphytica, 129:201209.

Harrison, D., S.S. Park, J. Ondov, T. Buckley, S.R. Kim, and R.K.M. Jayanty, 2004. Highly time resolved fine particle nitrate measurements at the Baltimore supersite. Atmos Environ., 38:53215332.

Harter, T., and J.R. Lund, 2012. Addressing Nitrate in California's Drinking Water; Report for the State Water Resources Control Board; Center for Watershed Sciences, University of California: Davis, CA, USA.

Hartz, T., and G.J. Hochmuth, 1996. Fertility management of drip-irrigated vegetables. HortTechnology, 6: 168-172.

Hartz, T.K., 2003. The assessment of soil and crop nutrient status in the development of efficient fertilizer recommendations. Acta Hort. 627: 231-240. [CrossRef]

Hartz, T.K., W.E. Bendixen, and L. Wierdsma, 2000.The value of presidedress soil nitrate testing as a nitrogen management tool in irrigated vegetable production. HortScience, 35: 651-656.

Hawkesford, M.J., and S. Griffiths, 2019. Exploiting genetic variation in nitrogen use efficiency for cereal crop improvement. Curr. Opin. Plant Biol., 49:35-42.

Haynes, R.J., 1990. Movement and transformations of fertigated nitrogen below trickle emitters and their effects on $\mathrm{pH}$ in the wetted soil volume. Fert. Res., 23:105-112. [CrossRef]

Hepperly, Y.P., D. Lotter, C.Z. Ulsh, R. Siedel, and C. Reider, 2009. Compost Sci Util., 17:117-126.

Herencia, J.F., P.A. García-Galavís, J.A.R. Dorado, and C. Maqueda, 2011. Comparison of nutritional quality of the crops grown in an organic and conventional fertilized soil. Sci. Hort. 129:882-888.

Hochmuth, G.J., 1994. Efficiency ranges for nitrate-nitrogen and potassium for vegetable petiole sap quick tests. HortTechnology, 4: 218-222.

Howell, T.A. 2003. Irrigation Efficiency; Marcel Dekker: New York, NY, USA. 
Iglesias-Bartolomé, R., C.A. González, and J.D. Kenis, 2004. Nitrate reductase dephosphorylation is induced by sugars and sugar-phosphates in corn leaf segments. Physiol. Plant., 122: 62-67. [CrossRef]

Incrocci, L. and L. Gestire, 2012. Nutrizione in serra con due software gratuiti. L'Inf. Agrar., 68: 5051.

Incrocci, L., M. Daniele and P. Alberto, 2017. New Trends in the Fertigation Management of Irrigated Vegetable Crops. Horticulturae, 3(37): 1-20

Incrocci, L., M. Daniele and P. Alberto, 2017. New Trends in the Fertigation Management of Irrigated Vegetable Crops Horticulturae 3, 37; doi:10.3390/horticulturae3020037.

International Commission on Irrigation and Drainage (ICID), 2016. Agricultural Water Management for Sustainable Rural Development: Annual Report 2015-2016; International Commission on Irrigation and Drainage: New Delhi, India,79-80.

Jiusheng, L. and L. Yuchun, 2011. Water and nitrate distributions as affected by layered textural soil and buried dripline depth under subsurface drip Fertigation Irrig. Sci. 29:469-478, DOI 10.1007/s00271-010-0255-z.

Judy, J. D., J. M. Unrine, W. Rao, S. Wirick, and P. M. Bertsch, 2012. Bioavailability of gold nanomaterials to plants: importance of particle size and surface coating. Environ. Sci. Technol., 46, 8467-8474. doi: 10.1021/es3019397

Jury W.A., and J.H. Vaux, 2005. The role of science in solving the world's emerging water problems, PNAS 102, 15715-15720.

Kafkafi, U. and J. Tarchitsky, 2011. Fertigation. A tool for efficient fertilizer and water.

Kang, S.Z., Z.S. Liang, Y.H. Pan, P.Z. Shi, and J.H. Zhang. 2000. Alternate furrow irrigation for maize production in an arid area. Agr. Water Manag., 45:267-274.

Karlberg, L., A. Ben-Gal, P.E. Jansson, and U. Shani, 2006. Modelling transpiration and growth in salinity stressed tomato under different climatic conditions. Ecol. Model, 190: 15-40. [CrossRef]

Khokhar, T., 2017. Globally, $70 \%$ of freshwater is used for agriculture. Available at: https://blogs.worldbank.org/opendata/ chart-globally-70-freshwater-used agriculture.

Konstantopoulo, E., E. Kapotis, G. Salachas, S.A. Petropoulos, I.C. Karapanos, and H.C. Passam, 2010. Nutritional quality of greenhouse lettuce at harvest and after storage in relation to $\mathrm{N}$ application and cultivation season. Sci. Hort., 125:93-95

Lamm, F.R. and C.R. Camp. 2007. Subsurface drip irrigation, p. 473-551. In: F.R. Lamm, J.E. Ayars, and F.S. Nakayama (eds.). Microirrigation for crop production: Design, operation, and management. Elsevier, Amsterdam, The Netherlands.

Lamm, J.E. Ayars, and F.S. Nakayama (eds.). Microirrigation for crop production: Design, operation, and management. Elsevier, Amsterdam, The Netherlands.

Larue, C., G. Veronesi, A.M. Flank, S. Surble, N. Herlin-Boime, and M. Carrière,2012. Comparative uptake and impact of $\mathrm{TiO} 2$ nanoparticles in wheat and rapeseed. J. Toxicol. Environ. Health A 75, 722-734. doi: 10.1080/15287394.2012.689800

Lemaire G., and A. Denoix, 1987. Croissance estivale en matière sèche de peuplements de fétuque élevée (Festuca arundinacea Schreb.) et de dactyle (Dactylis glomerata L.) dans l'Ouest de la France. II. Interaction entre les niveaux d'alimentation hydrique et de nutrition azotée, Agronomie, 7:381-389.

Leskovar, D.I., J.C. Ward, W. Russell, R.W. Sprague, and A. Meiri, 2001. Yield, quality, and water use efficiency of muskmelon are affected by irrigation and transplanting versus direct seeding. HortScience 36:286-291.

Li, J., J. Zhang, and M. Rao, 2004. Wetting patterns and nitrogen distributions as affected by Fertigation strategies from a surface point source. Agric. Water Manag., 67: 89-104. [CrossRef]

Liu, R., and R. Lal, 2015. Potentials of engineered nanoparticles as fertilizers for increasing agronomic productions. Sci. Total Environ. 514:131- 139.

Lorenz, H.P., J. Schlaghecken, G. Engl, A. Maync, J. Ziegler, M. Kohl, and K. Strohmeyer, 1989. Ordnungsgemasse Stickstoff-Versorgung im Freiland-Gemusebau nach dem "Kulturbegleitenden Nmin-Sollwerte (KNS)-System" Mìnìsterium fur Landwìrtschaft, Weinbau und Forsten: Rheìnland Pfalz, Maìnz, 85.

Luo, J., S. Sun, L. Jia, W. Chen, and Q. Shen, 2006. The mechanism of nitrate accumulation in pakchoi [Brassica campestris L. ssp. Chinensis (L.)]. Plant Soil, 282:291-300 
M'hamdi, M., G. Abid, H. Chikh-Rouhou, N. Razgallah, and A. Hassen, 2016. Effect of genotype and growing season on nitrate accumulation and expression patterns of nitrate transporter genes in potato (Solanum tuberosum L.). Arch. Agron. Soil Sci. 62:1508-1520.

Ma, X., J. Geisler-Lee, Y. Deng, and A. Kolmakov, 2010. Interactions between engineered nanoparticles (ENPs) and plants: phytotoxicity, uptake and accumulation. Sci. Total Environ. 408, 3053-3061. doi: 10.1016/j.scitotenv.2010.03.031

Mahmoodabadi M, RS Amini, and K Khazaeepour, 2010. Using animal manure for improving soil chemical properties under different leaching conditions. Middle East J. Sci. Res. 5:214- 217.

Manor, S., A. Lowengart, M. Brum, A. Hazan, I. Bar, and S. Geva, 1983. The technology of chemigation: Uniformity of Distribution in the Irrigation. In 3rd International Conference on Irrigation, Tel-Aviv, Israel, 3-6 October.

Marcel G. A., H. Van der and S. Klaus, 2015. Root surface as a frontier for plant microbiome research, COMMENTARY, 24, 2015 | 112 (8): 2299-2300.

Marcelis, L.F.M., E. Heuvelink, and J. Goudriaan, 1998. Modelling biomass production and yield of horticultural crops: A review. Sci. Hortic., 74: 83-111. [CrossRef]

Marcelo L.C.E., N.S.D. Leonardo, C.M.D. Allan, F.S. Claudinei, and E.E., Matsura, 2015. Wet Bulbs From The Subsurface Drip Irrigation With Water Supply And Treated Sewage Effluent, Journal of the Brazilian Association of Agricultural Engineering. Doi:http://dx.doi.org/10.1590/18094430 .

Mark, R.W., R.B. Anthony, A.E. Herschel, S.C. Amy, D. Curtis, and J.A.K. Peter, 2015. Linking Nitrogen Management, Seep Chemistry, and Stream Water Quality in Two Agricultural Headwater Watersheds, Journal of Environmental Quality DOI: 10.2134/jeq2014.10.0412.

Miller, A.J., X. Fan, M. Orsel, S.J. Smith, and D.M. Wells, 2007. Nitrate transport and signalling. J. Exp. Bot., 58: 2297-2306. [CrossRef]

Moddassir, A., R. Muhammad, A. Muhammad, M. Zahid, and A.S. Nasir, 2020. Hazards of nitrogen fertilizers and ways to reduce nitrate accumulation in crop plants Environmental Science and Pollution Research 27:17661 17670.

Mohamed G.E., M.B. Khaled, M.N. Abdelazim and Y. Chihiro, 2019. Evaluation of Root Water Uptake and Urea Fertigation Distribution under Subsurface Drip Irrigation. Water 2019, 11, 1487; doi: 10.3390-w1107-1487.

Monostori, I., F. Szira, A. Tondelli, T Arendas, K. Gierczik, L. Cattivelli, G. Galiba, and A. Vagujfalvi, 2017. Genome-wide association study and genetic diversity analysis on nitrogen use efficiency in a central European winter wheat (Triticum aestivum L.) collection. PLoS One 12

Muñoz-Huerta, R.F., R.G. Guevara-Gonzalez, L.M. Contreras-Medina, I. Torres-Pacheco, J. PradoOlivarez, and R.V. Ocampo-Velazquez, 2013.A review of methods for sensing the nitrogen status in plants: Advantages, disadvantages and recent advances. Sensors, 13, 10823-10843. [CrossRef] [PubMed]

Navarro, E., A. Baun, R. Behra, N.B. Hartmann, J. Filser, A.J. Miao, et al., 2008. Environmental behavior and ecotoxicity of engineered nanoparticles to algae, plants, and fungi. Ecotoxicology 17, 372-386. doi: 10.1007/s10646-008-0214-0

Nishina, H., 2015. Development of speaking plant approach technique for intelligent greenhouse. Agric. Agric. Sci. Proc., 3: 9-13. [CrossRef]

Nunez de Gonzalez, M.T., W.N. Osburn, M.D. Hardin, M. Longnecker, H.K. Garg, N.S. Bryan, and J.T. Keeton, 2015. A survey of nitrate and nitrite concentrations in conventional and organic labeled raw vegetables at retail. J Food Sci., 80:C942-C949.

OECD., 2010. Sustainable Management of Water Resources in Agriculture. ISBN 978-92-64 08345-5 (print). DOI 10.1787/9789264083578-en Postel, S. - Polak, P. - Gonzales, F. - Keller J. 2001. Drip irrigation for small farmers. A new initiative to alleviate hunger and poverty. In Water Intern., 26, 2001(1): 3-13.

Oliver, M.A. and P.J. Gregory, 2015. Soil, food security and human health: a review. Eur J Soil Sci., 66: $257-276$.

Onillon B., J.L. Durand, F. Gastal, and R. Tournebize, 1995. Drought effects on growth and carbon partitioning in a tall fescue sward grown at different rates of nitrogen fertilization, Eur. J. Agron., 4: 91-99. 
Padilla, F.M., M. Teresa Peña-Fleitas, M. Gallardo, and R.B. Thompson, 2014. Evaluation of optical sensor measurements of canopy reflectance and of leaf flavonols and chlorophyll contents to assess crop nitrogen status of muskmelon. Eur. J. Agric., 58, 39-52. [CrossRef]

Padilla, F.M., M.T. Peña-Fleitas, M. Gallardo, and R.B. Thompson, 2015.Threshold values of canopy reflectance indices and chlorophyll meter readings for optimal nitrogen nutrition of tomato. Ann. Appl. Biol., 166: 271-285. [CrossRef]

Pardossi, A., and L. Incrocci, 2011. Traditional and new approaches to irrigation scheduling in vegetable crops. HortTechnology, 21: 309-313.

Parks, S.E., D.E. Irving, and P.J. Milham, 2012. A critical evaluation of on-farm rapid tests for measuring nitrate in leafy vegetables. Sci. Hortic., 134: 1-6. [CrossRef]

Pavlou, G.C., C.D. Ehaliotis, and V.A. Kavvadias, 2007. Effect of organic and inorganic fertilizers applied during successive crop seasons on growth and nitrate accumulation in lettuce. Sci Hort 111:319-325.

Peña-Fleitas, M.T., M. Gallardo, R.B. Thompson, M. Farneselli, and F.M. Padilla, 2015. Assessing crop $\mathrm{N}$ status of fertigated vegetable crops using plant and soil monitoring techniques. Ann. Appl. Biol., [CrossRef] [PubMed]

Prasetyo, W., M. Santoso, and T. Wardiyanti, 2013. Pengaruh beberapa macam kombinasi pupuk organik dan anorganik terhadap pertumbuhan dan hasil tanaman jagung manis (Zea Mays Saccharata Sturt). J Plant Production 1:79-86.

Purbajanti, E.D., W. Slamet, E. Fuskhah, and R. Rosyida, 2019. Effects of organic and inorganic fertilizers on growth, activity of nitrate reductase and chlorophyll contents of peanuts (Arachis hypogaea L.). IOP Conf Ser: Earth Environ Sci 250:012048.

Qiu, W., Z. Wang, C. Huang, B. Chen, and R. Yang, 2014. Nitrate accumulation in leafy vegetables and its relationship with water. J Soil Sci Plant Nutr., 14:761-768.

Raliya, R., C. Franke, S. Chavalmane, R. Nair, N. Reed, and P. Biswas, 2016. Quantitative understanding of nanoparticle uptake in watermelon plants. Front. Plant Sci., 7:1288. doi: 10.3389/fpls.2016.01288.

Rathod, K.S., S. Velmurugan, and A. Ahluwalia, 2016. A 'green' diet-based approach to cardiovascular health? Is inorganic nitrate the answer? Mol. Nutr. Food Res., 60:185-202.

Razgallah, N., G. Abid, H. Chikh-Rouhou, A. Hassen, and M. M'hamdi, 2017. Nitrate content and expression of putative nitrate transporter genes in lettuce fertilized with nitrogen fertilizers. Intl $\mathrm{J}$ Vegetable Sci., 23:173-184.

Reinders, F.B., 2007. Micro-irrigation: World overview on technology and utilization. In Proceedings of the 7th International Micro-Irrigation Congress, Kuala Lumpur, Malaysia, 13-15 September.

Renseigné, N., S. Umar, and M. Iqbal, 2007. Nitrate accumulation in plants, factors affecting the process, and human health implications. A review Agron. Sustain Dev. 27:45-57.

Rico, C. M., S. Majumdar, M. Duarte-Gardea, J. R. Peralta-Videa, and J.L. GardeaTorresdey, 2011. Interaction of nanoparticles with edible plants and their possible implications in the food chain. J. Agric. Food Chem., 59, 3485-3498. doi: 10.1021/jf104517j

Riens, B., and H.W. Heldt, 1992. Decrease of nitrate reductase activity in spinach leaves during a light dark transition. Plant Physio., 1 98:573-577.

Ruan, Y.L., Y. Jin, Y.J. Yang, G.J. Li, and J.S. Boyer, 2010. Sugar input, metabolism, and signaling mediated by invertase: Roles in development, yield potential, and response to drought and heat. Mol. Plant, 3: 942-955. [CrossRef].

Sabo-Attwood, T., J.M. Unrine, J.W. Stone, C.J. Murphy, S. Ghoshroy, D. Blom, et al., 2012. Uptake, distribution and toxicity of gold nanoparticles in tobacco (Nicotiana xanthi) seedlings. Nanotoxicology 6, 353-360. doi: 10.3109/17435390.2011.579631

Sagiv, B., and U. Kafkafi, 1976. Fertilization and manuring of pepper plants in sandy soils. Hassadeh, 56:1726-1730.

Sagiv, B., B. Bar-Yosef, and E. Eliah, 1980. Drip Irrigation and Fertilization of Spring Muskmelon at Besor; Pub. No. 17; Division of Scientific Publications, The Volcani Center: Bet Dagan, Israel.

Samborski, S.M., N. Tremblay, and E. Fallon, 2009. Strategies to make use of plant sensor-based diagnostic information for nitrogen recommendations. Agron. J., 101: 800-816. [CrossRef]

Santamaria, P, 2006. Nitrate in vegetables: toxicity, content, intake and EC regulation. J. Sci. Food Agric., 86:10-17. 
Santamaria, P., 2006. Nitrate in vegetables: toxicity, content, intake and EC regulation, J. Sci. Food Agr., 86: 10-17.

Santamaria, P., A. Elia, F. Serio, and E. Todaro, 1999. A survey of nitrate and oxalate content in fresh vegetables. J. Sci. Food Agric., 79:1882-1888

Santamaria, P., A. Elia, M. Gonnella, A. Parente, and F. Serio, 2001. Ways of reducing rocket salad nitrate content. Acta. Hort., 548:529-537.

Schoebitz, M., and G. Vidal, 2016. Microbial consortium and pig slurry to improve chemical properties of degraded soil and nutrient plant uptake. J Soil Sci Plant Nutr., 16:226-236.

Schwab, F., G. Zhai, M. Kern, A. Turner, J.L. Schnoor, and M.R. Wiesner,2015. Barriers, pathways and processes for uptake, translocation and accumulation of nanomaterials in plants-Critical review. Nanotoxicology, 10: 257-278. doi: 10.3109/17435390.2015.1048326.

Schwab, F., G. Zhai, M. Kern, A. Turner, J.L. Schnoor, and M.R. Wiesner, 2015. Barriers, pathways and processes for uptake, translocation and accumulation of nanomaterials in plants-Critical review. Nanotoxicology ,10: 257-278. doi: 10.3109/17435390.2015.1048326.

Schwankl, L., B. Hanson, and T. Prichard, 1998. Micro-irrigation of trees and vines: A handbook for water managers. Publ. 3378. Oakland, CA: Div. Agr. Natural Resources, Univ. Calif.

Shedeed, S.I., S.M. Zaghloul, and A. Yassen, 2009. Effect of method and rate of fertilizer application under drip irrigation on yield and nutrient uptake by tomato. Ozean J. Appl. Sci., 2: 139-147.

Sheehy J., 2001. Will yield barriers limit future rice production? in: Nösberger J., Geiger H.H., Struik P.C. (Eds.), Crop Science and Prospect, CABI Publishing): 281-306.

Silberbush, M., and J.H. Lieth, 2004.Nitrate and potassium uptake by greenhouse roses (Rosa hybrida) along successive flower-cut cycles: A model and its calibration. Sci. Hortic., 101: 127-141. [CrossRef]

Simonne, E., D. Studstill, and R.C. Hochmuth, 2006. Understanding water movement in mulched beds on sandy soils: An approach to ecologically sound fertigation in vegetable production. Acta Hortic., 700: 173-178.[CrossRef]

Simonne, E., H. Robert, B. Jacque, L. William, T. Danielle, and G. Aparna, 2012. Drip-Irrigation Systems for Small Conventional Vegetable Farms and Organic Vegetable Farms production in Florida, EDIS Publication HS737, http://edis. ifas.ufl.edu/cv135.

Simonne, E.H., D.W. Studstill, R.C. Hochmuth, T. Olczyk, M. Dukes, R. Munoz-Carpena, and Y. Li, 2017. Drip Irrigation: The BPM Era - an Integrated Approach to Water and Fertilizer Management for Vegetables Grown with Plasticulture. HS917. Gainesville: University of Florida Institute of Food and Agricultural Sciences. http://edis.ifas. ufl.edu/hs172

Šim $u^{\circ}$ nek, J., M.T. van Genuchten, and M. Šejna, 2007. Modeling Subsurface Water Flow and Solute Transport with HYDRUS and Related Numerical Software Packages; Garcia-Navarro, P., Ed., Numerical Modelling of Hydrodynamics for Water Resources; Taylor \& Francis Group: London, UK.

Singh, B. and Y. Singh, 2015. Soil Fertility: Evaluation and Management. In. Rattan, R.K. Katyal, J.C.

Smith, M. 1999. Manual of CROPWAT Computer Program; FAO Irrigation and Drainage Paper No. 52; FAO: Rome, Italy,

Solaimalai, A., M. Baskar, A. Sadasakthi, and K. Subburamu, 2005. Fertigation in high value cropsA review. Agric. Rev., 1: 1-13.

Soleymani, A., and M.H. Shahrajabian, 2012. Effects of different levels of nitrogen on yield and nitrate content of four spring onion genotypes. Intl. J. Agric. Crop Sci. 4:179-182

Sonneveld, C., and W. Voogt, 2009. Plant Nutrition of Greenhouse Crops; Springer: New York, NY, USA, 350 .

Srinivas, K., D.M. Hegde, and G.V. Havanagi, 1989. Irrigation studies of watermelon (Citrullus lanatus (Thunb) Matsum et Nakai). Irr. Sci. 10:293-301.

Stefania D.P., D.C. Luisa, V. Simona, B.Giancarlo, and M. Albino, 2011. Increasing Water Use Efficiency in Vegetable Crop Production: From Plant to Irrigation Systems Efficiency. HortTechnology, 21(3):301-308.

Swiader, J.M., and A. Moore, 2002. Spad-chlorophyll response to nitrogen fertilization and evaluation of nitrogen status in dryland and irrigated pumpkins. J. Plant Nutr., 25: 1089-1100. [CrossRef]

Talouizite A., and M.L. Champigny, 1988. Response of wheat seedlings to short-term drought stress with particular respect to nitrate utilisation, Plant Cell Environ. 11: 149-155. 
Taylor, A. F., E.L. Rylott, C.W. Anderson, and N.C. Bruce, 2014. Investigating the toxicity, uptake, nanoparticle formation and genetic response of plants to gold. PLoS ONE 9:e93793. doi: 10.1371/journal.pone.0093793.

Tei, F., P. Benincasa, and M. Guiducci, 1999. Nitrogen fertilisation on lettuce, processing tomato and sweet pepper: Yield, nitrogen uptake and the risk of nitrate leaching. Acta Hortic., 506:6167.[CrossRef]

Thompson, A.J., J. Andrews, B.J. Mulholland, J.M. McKee, H.W. Hilton, J.S. Horridge, G.D. Farquhar, R.C. Smeeton, I.R. Smillie, C.R. Black, and I.B. Taylor, 2007. Overproduction of abscisic acid in tomato increases transpiration efficiency and root hydraulic conductivity and influences leaf expansion. Plant Physiol. 143:1905-1917.

Thompson, R.B., C. Martínez-Gaitán, M. Gallardo, C. Giménez, and M.D. Fernández, 2007. Identification of irrigation and $\mathrm{N}$ management practices that contribute to nitrate leaching loss from an intensive vegetable production system by use of a comprehensive survey. Agric. Water Manag., 89: 261-274. [CrossRef]

Thompson, R.B., L. Incrocci, W. Voogt, A. Pardossi, and J.J. Magán, 2017. Sustainable irrigation and nitrogen management of fertigated vegetable crops. Acta Hortic., 1150:363-378. [CrossRef]

Thompson, R.B., M. Gallardo, J.S. Rodríguez, J.A. Sánchez, and J.J. Magán, 2013. Effect of N uptake concentration on nitrate leaching from tomato grown in free-draining soilless culture under Mediterranean conditions. Sci. Hortic., 150: 387-398. [CrossRef]

Thompson, R.B., M. Gallardo, M. Joya, C. Segovia, C. Martínez-Gaitán, and M.R. Granados, 2009. Evaluation of rapid analysis systems for on-farm nitrate analysis in vegetable cropping. Span. J. Agric. Res., 7: 200-211. [CrossRef]

Thompson, T.L. and T.A. Doerge, 1995. Nitrogen and water rates for subsurface trickle-irrigated romaine lettuce. Hort-Science, 30:1233-1237.

Thornley, J.H.M., 1998. Dynamic model of leaf photosynthesis with acclimation to light and nitrogen. Ann. Bot., 81: 421-430. [CrossRef]

Thornley, J.H.M., and I.R. Johnson, 1990. Plant and Crop Modelling: A Mathematical Approach to Plant and Crop Physiology; Clarendon Press: Oxford, UK, 670.

Tiwari, K.N., P.K. Mal, R.M. Singh, and A. Chattopadhyay, 1998. Response of okra (Abelmoschus esculentus L.) to drip irrigation under mulch and non-mulch conditions. Agr. Water Mgt. 38:91102.

Tiwari, K.N., S. Singh, and P.K. Mal, 2003. Effect of drip irrigation on yield of cabbage (Brassica oleracea L. var. capitata) under mulch and non-mulch conditions. Agr. Water Mgt. 58:19-28.

Tremblay, N., C. Bélec, S. Jenni, E. Fortier, and R. Mellgren, 2009. The dualex-A new tool to determine nitrogen sufficiency in broccoli. Acta Hortic., 824: 121-132. [CrossRef]

Tyree, M., 2003.The ascent of water. Nature, 423:923.

Usha, K., and B. Singh, 2013. Potential applications of remote sensing in horticulture-A review. Sci. Hortic., 153: 71-83. [CrossRef]

Üzen, N. and Ö. Çetin, 2016. Effects of nitrogen fertigation frequency on yield and nitrogen retention in drip-irrigated cotton. In Journal of Plant Nutrition, 39(14): 2126-2135.

Üzen, N., Ö. Çetin, and M. Karaer, 2013. Micro Irrigation for Modern Agriculture. 1st Central Asia Congress on Modern Agricultural Techniques and Plant Nutrition, Bishkek, Kyrgyzstan, 01-03 October): 2131-2138.

Van den Bos, A.L., C. de Kreij, and W. Voogt, 1999. Bemestingsadviesbasis Grond; Proefstation voor Bloemisterij en Glasgroente: Naaldwijk, 54.

Van Diepen, C.A., J. Wolf, van Keulen, H., Rappoldt, and C. Wofost, 1989. A simulation model of crop production. Soil Use Manag., 5: 16-24. [CrossRef]

Voogt, W., F. Steinbuch, and A. van Winkel, 2006. Evaluation of the 'fertigation model', a decision support system for water and nutrient supply for soil grown greenhouse crops. Acta Hortic. 718: 531-538. [CrossRef]

Voogt, W., J.A. Kipp, R. de Graaf, and L. Spaans, 2000. A fertigation model for glasshouse crops grown in soil. Acta Hortic. 537: 495-502. [CrossRef]

Walker, B.J., D.D. Strand, D.M. Kramer, and A.B. Cousins, 2014. The response of cyclic electron flow around photosystem I to changes in photorespiration and nitrate assimilation. Plant Physiol., 165: 453-462.[CrossRef] 
Wallace, J.S., 2000. Increasing agricultural water use efficiency to meet future food production. In Agriculture, Ecosystems and Environment, (82): 105-119.

Wang, F., X. Liu, Z. Shi, R. Tong, C. A. Adams, and X. Shi, 2016. Arbuscular mycorrhizae alleviate negative effects of zinc oxide nanoparticle and zinc accumulation in maize plants A soil microcosm experiment. Chemosphere 147: 88-97. doi: 10.1016/j.chemosphere.2015.12.076

Wang, Y.P., 2000. A refinement to the two-leaf model for calculating canopy photosynthesis. Agr. For. Meteorol., 101: 143-150. [CrossRef]

Wang, Y.Y., and Y.F. Tsay, 2011. Arabidopsis nitrate transporter NRT1.9 is important in phloem nitrate transport. Plant Cell, 23: 1945-1957. [CrossRef]

Wang, Z., and S. Li, 2004. Effects of nitrogen and phosphorus fertilization on plant growth and nitrate accumulation in vegetables. J. Plant Nutr. 27: 539-556

Webb, T.H., L.R. Lilburne, and G.S. Francis, 2001.Validation of the GLEAMS simulation model for estimating net nitrogen mineralisation and nitrate leaching under cropping in Canterbury, New Zealand. Aust. J. Soil Res., 39: 1015-1025. [CrossRef]

Wichelns, D. 2007. Economic implications of microirrigation, p. 221-259. In: Lamm F.R., Ayars J.E., and F.S. Nakayama (eds.). Microirrigation for crop production: Design, operation, and management. Elsevier, Amsterdam, The Netherlands.

Wu, J.D., D. Wang, C.J. Rosen, and M.E. Bauer, 2007. Comparison of petiole nitrate concentrations, SPAD chlorophyll readings, and QuickBird satellite imagery in detecting nitrogen status of potato canopies. Field Crops Res., 101: 96-103. [CrossRef]

Yan, X.L., T.F. Dai, and L.M. Jia, 2018. Evaluation of the cumulative effect of drip irrigation and fertigation on productivity in a poplar plantation. In Annals of Forest Science, 75: 5.

Yao Z., Z. Dabin, Y. Pengwei, Z. Na, L. Yangyang, Z. Suiqi, Z. Bingnian, H. Donglin, M. Aisheng, Z.Yajie, C. Weidong, and G. Yajun, 2018. Optimizing the synthetic nitrogen rate to balance residual nitrate and crop yield in a leguminous green-manured wheat cropping system Science of the Total Environment 631-632, 1234-1242.

Yokota, M., T. Okada, and I. Yamaguchi, 2007. An optical sensor for analysis of soil nutrients by using LED light sources. Meas. Sci. Technol., 18: 2197-2201. [CrossRef]

Yolcu, R., and Ö. Çetin, 2015. Nitrogen fertigation to improve nitrogen use efficiency and crude protein on silage corn. In Turk J Field Crops, 20, 2015(2): 233-241.

Yuan, B.-Z., J. Sun, Y. Kang, and S. Nishiyama. 2006. Response of cucumber to drip irrigation water under a rainshelter. Agr. Water Mgt. 81:145-158.

Zhang, K., D. Yang, D.J. Greenwood, C.R. Rahn, and K. Thorup-Kristensen, 2009. Development and critical evaluation of a generic 2-D agro-hydrological model (SMCR_N) for the responses of crop yield and nitrogen composition to nitrogen fertilizer. Agric. Ecosyst. Environ., 132: 160-172. [CrossRef]

Zhang, K., D.J. Greenwood, W.P. Spracklen, C.R. Rahn, J.P. Hammond, P.J. White, and I.G. Burns, 2010. A universal agro-hydrological model for water and nitrogen cycles in the soil-crop system SMCR_N: Critical update and further validation. Agric. Water Manag. 97: 1411-1422. [CrossRef]

Zhonghua, B., W. Yu, Z. Xiaoyan, L. Tao, G. Steven, Y. Qichang and C. Ruifeng, 2020. A Review of Environment Effects on Nitrate Accumulation in Leafy Vegetables Grown in Controlled Environments. Foods 9, 732; doi:10.3390/foods9060732

Zhou, Z.Y., M.J. Wang, and J.S. Wang, 2000. Nitrate and nitrite contamination in vegetables in China. Food Rev Intl 16:61-76.

Zhu, Z. J., H. Wang, B. Yan, H. Zheng, Y. Jiang, O.R. Miranda, et al., 2012. Effect of surface charge on the uptake and distribution of gold nanoparticles in four plant species. Environ. Sci. Technol. 46, 12391-12398. doi: 10.1021/es301977w.

Ziegler, J., K. Strohmeier, and T. Brand, 1996. Nitrogen supply of vegetables based on the "KNSsystem“. Acta Hortic., 428: 223-233. [CrossRef] 